\title{
INDUSTRIAL WATER POLLUTION AND THE REFUSE ACT: A SECOND CHANCE FOR WATER QUALITY
}

\author{
WIITTAM H. RoDgers, JR. $\dagger$
}

On July 12, 1970, Senator Philip A. Hart, Chairman of the Senate Subcommittee on Energy, Natural Resources, and the Environment, announced the scheduling of additional hearings to consider mercury contamination of the nation's waterways. For several months, ominous news from Sweden, Japan, Canada, and across the United States disclosed mounting evidence of contamination ${ }^{1}$ and its effects, ${ }^{2}$ shocking to research scientists and government officials alike. Immediately Secretary of the Interior Walter Hickel sent telegrams to the governors of seventeen states in which mercury pollution was suspected urging that "abatement action . . . be initiated at once" 3 and warning that "The Administration is developing hard evidence and will seek court action in any confirmed case of mercury pollution if corrective measures are not taken swiftly on local levels." 4 Five days before the opening of the subcommittee hearings, Secretary Hickel announced that the Justice Department would file charges against ten industrial plants which were polluting waterways with mercury. ${ }^{5}$

Of some surprise in the Administration's reaction to the mercury findings was its decision to ignore the Water Quality Improvement Act of $1970 .^{6}$ By any view, mercury in the water environment constitutes a "hazardous substance" - a designation the President could decree under

† Associate Professor of Law, University of Washington. B.A. 1961, Harvard University; LL.B. 1965, Columbia University. Member, New York and Washington Bars. The author was co-counsel in the case cited in note 133 infra.

${ }^{1}$ See, e.g., N.Y. Times, Aug. 10, 1970, at 1, col. 8; Spectrum, 12 ENVIronmEnt, Oct. 1970 , at S-1.

2 See U.S. Dep'T of the Intertor, Mercury Contamination in the Naturad ENVIRONALEN: A COOPERATIVE BIBLIOGRAPHY (1970); Hearings on the Effects of Mercury on Man \& the Environment Before the Subcomm. on Energy, Natural Resources $\mathcal{E}$ the Enviromnent of the Sentate Comm. on Commerce, 91st Cong., 2d Sess. (1970) [hereinafter cited as Mercury Hearings]; N.Y. Times, Sept. 11, 1970, at 1, col. 1 .

3 Secretary Hickel Moves Against Mercury Pollution, U.S. Dep't of the Interior News Release No. 26456, at 3 (July 14, 1970).

4 Id. 1.

5 Charges Filed Against Mercury Polluters, U.S. Dep't of the Interior News Release No. 26748 (July 24, 1970).

6 Water Quality Improvement Act of $1970 \$ 102,33$ U.S.C.A. $\$ 1162$ (1970). This act is codified at 33 U.S.C.A. \$\$ $1151-75$ (1970), annending Federal Water Pollution Control Act of 1948, as amended, 33 U.S.C. \$\$ 466-66n (Supp. V, 1970); see Exec. Order No. 11,574, 3 C.F.R. 188 (Supp. 1970) (administration of Refuse Act permit program); cf. Exec. Order No. 11,507, §3(a)(1), 3 C.F.R. 91 (Supp. $1970)$ (prevention, control, and abatement of air and water poliution at federai facilities). 
the authority of the 1970 Act to implement speedy steps to eliminate the threat. The legal response, instead, took the form of filing actions under the Rivers and Harbors Act of 1899, more commonly known as the Refuse Act. ${ }^{7}$ That the solons of the nineteenth century appear to have surpassed their modern successors in fashioning useful tools for combatting water pollution is a curious commentary on the accidents of legal history and on the vitality of the current drive to secure water quality. This Article focuses upon the use of the recently revived Refuse Act as a deterrent to industrial water pollution and as a spur to securing the necessary process and treatment changes.

Rarely is a broad regulatory effort revived substantially by the rediscovery of a long-ignored law. The primary purpose of this Article is to encourage a forceful implementation of the Refuse Act as a second chance to achieve water quality. The presentation commences in Section I with a brief outline of the dimensions of industrial water pollution and the legal and scientific barriers to effective control. Against this background, Section II summarizes the central features of the Refuse Act, presents a narrative history of its recent renovation, and analyzes the major issues arising under the statute. Section III discusses the traditional industrial and governmental view of water pollution and how a change in regulatory attitude invites revitalization of the Refuse Act. The discrete roles of the private citizen, the Department of Justice, the Army Corps of Engineers (the Corps), and the Environmental Protection Agency (EPA) are discussed critically in Section IV with the aim of aborting regulatory blunders which might retard improvements in water quality that could be achieved through the wise use of the 1899 Act. The Article concludes in Section V by presenting two scenarios of polar utilizations of the Refuse Act, which may unfold within the next few years-one optimistic, the other pessimistic, either quite possible.

\section{The Problem}

Little has been written to assist the legal profession in understanding the ominous biological and chemical dimensions of industrial

7 Act of Mar. 3, 1899, ch. 425, §13, 30 Stat. 1152, as amended, 33 U.S.C. \$\$ 40115 (1964).

The 1970 Act does not in any way supersede or repeal the Refuse Act prohibitions. United States v. Maplewood Poultry, 2 BNA ENv. REP. 1646, 1648 (D. Me. June 10, 1971) (citing 33 U.S.C.A. \$1174 (1970)). For a discussion of the many shortcomings of the Federal Water Pollution Control Act, including the 1970 amendments, and an analysis of the interrelationships of the two Acts, see Note, The Refuse Act: Its Role Within the Scheme of Federal Water Quality Legislation, 46 N.Y.U.L. REv. 304, 319-23 (1971). For illustrations of the ineffectiveness of past FWQA proceedings, see text accompanying notes 230-52. 
water pollution. ${ }^{8}$ Indeed, modern industrial effuent is a menace of largely unknown scientific parameters. "While the locations of most of the major waste discharges are known," reports the Secretary of the Interior in the 1970 National Estuarine Pollution Study, "information on the characteristics of individual waste effluents is extremely limited. In particular, knowledge of the characteristics of individual industrial waste discharges is very poor, and data on them are extremely scattered." : At least in part our ignorance in the field of water pollution stems from years of inaction in implementing a national inventory of water wastes to expose the dimensions of the pollution problem. ${ }^{10}$ Opposition from industrial sources fearful of federal bureaucratic interference, irresponsible reporters, and trade secret disclosures ${ }^{11}$ have contributed to the delay. ${ }^{12}$ That the Federal Water Quality Administration (FWQA), now within EPA, ${ }^{13}$ has at last distributed a questionnaire to industrial polluters merely raises the possibility that useful information will be forthcoming. ${ }^{14}$

Data on water quality is similarly scanty. "In the final analysis, the greatest deficiency in basic information on estuaries," according to

8 Useful sources include Hines, Controlling Industrial Water Pollution: Color the Problem Green, 9 B.C. InD. \& Con. L. Rev. 553 (1968) ; Reitze, Wastes, Water, and Wishful Thinking: The Battle of Lake Erie, 20 CASE W. Res. L. Rev. 5 (1968); and NADER TASK FORCE REPORT ON WATER POLlution: Water Wasteland (D. Zwick ed. 1971) [hereinafter cited as NADER REPORT].

9 Secretary of the Interior, Report on the National Estuarine Pollution Study, S. Doc. No. 58, 91st Cong., 2d Sess. 530 (1970) [hereinafter cited as Estuarine Study] .

10 See House Comrar. on Gov't Operations, The Critical Need for a National INVENTORY OF INDUSTRIAL WAstes (Water POLIUTION CoNTrol AND ABATEMENT), H.R. REp. No. 1579, 90th Cong., 2d Sess. 13 (1968); Hearings on S. 3067 Before the Subcomm. on Intergovernmental Relations of the Senate Comm. on Gov't Operations, 91st Cong., 2d Sess. (1970) ; Hearings on the Establishment of a National Industrial Wastes Inventory Before the Subcomm. on Conservation and Natural Resources of the House Comm. on Gov't Operations, 91st Cong., 2d Sess. (1970) (testimony of FWQA Comm'r Dominick) [hereinafter cited as Wastes Inventory Hearings].

11 Wastes Inventory Hearings, supra note 10 , at 45 (statement of William $\mathrm{H}$. Rodgers, Jr., upon which observations in text are based).

12 Some of the reasons for industry opposition to the national waste inventory were disclosed in hearings conducted by the Special Studies Subcommittee of the House Committee on Gov't Operations. Hearings on Presidential Advisory Committees Before the Special Studies Subcomm. of the Honse Comm. on Gov't Operations, 91st Cong., 2d Sess. 144 (1970) (minutes of the Panel on Proposed U.S. Public Health Service Survey of Industrial Waste Water Disposal, June 9, 1964). Concern was expressed that the data could be misused for political purposes, and that any confidential information supplied might be used against the industries. Id. 147 (minutes of the Panel on Proposed Survey of Industrial Waste Water Disposal, August 13, 1968).

13 Under the Presidential reorganization plans, the transfer of FWQA from the Department of the Interior to EPA was effected. See MESSAGE FROM THE President Before the Subcomm. on Conservation of the House Comis. on Gov't Operations, Hearings on Reorganization. Plans Nos. 3 and 4 of 1970, H.R. Doc. No. 366, 91 st Cong., 2d Sess. (1970).

14 See Wastes Inventory Hearings, supra note 10, at 6 (testimony of FWQA Comm'r Dominick). 
the National Estuarine Pollution Study, "is the lack of water quality data . . . "15 A national water quality monitoring system is still largely in the planning stages. A law review article published in 1970 recommends legislation to authorize the establishment of a federal water pollution surveillance system and to grant authority for site acquisition and the procurement of equipment. ${ }^{16}$ But, if implemented, such a system will be able to monitor only a few of the variables determining water quality. ${ }^{17}$ The staggering complexities of industrial effluents produced by constantly changing processes, particularly in the organic field, overwhelm the primitive detection techniques of enforcement officials, ${ }^{18}$ and many compounds cannot be detected by present automated equipment. ${ }^{19}$

Over 300,000 water-using factories are located in the United States, ${ }^{20}$ two-thirds of them in the coastal states. ${ }^{21}$ Roughly 10,000 establishments are responsible for ninety percent of the water used by industry. ${ }^{22}$ In the coastal states, two percent of the plants generate ninety-seven percent of the total liquid wastes. ${ }^{23}$ Of nearly 22 billion gallons of wastes discharged daily, twenty-nine percent receive treatment. ${ }^{24}$ Manufacturing establishments are now believed responsible for about three times the organic waste load of municipalities, ${ }^{25}$ a sharp upward revision from the estimates of a few years ago. ${ }^{26}$ Industry's current fifty-percent share of the nation's water requirements is ex-

15 Estuarine Study, supra note 9, at 549.

16 Brown \& Duncan, Legal Aspects of a Federal Water Quality Surveillance System, 68 MICH. L. Rev. 1131, 1132 \& n.6 (1970).

17 See Hearings on Water Pollution Control \& Abatement Before the Subcomm. on Natural Resources \& Power of the House Comm. on Gov't Operations, 88th Cong., 1st Sess., pt. 1A, at 241-42 (1963) (statement of Richard S. Green, Chief, Basic Data Branch, Division of Water Supply \& Pollution Control, U.S. Public Health Service) [hereinafter cited as 1963 Hearings].

18 Id. 195.

19 See note 17 supra. ' Since 1963 automated monitoring capabilities have not improved significantly. See Hearings on Water Pollution Control Prograns Before the Subcomm. on Air \& Water Pollution of the Senate Comm. on Commerce, 92d Cong., 1st Sess. 652-53 (1971) [hereinafter cited as 1971 Hearings]; MESSAGE FRoM the President to the House Comm. on Public Works, Control of Hazardous Polluting Substances, H.R. Doc. No. 70, 92d Cong., 1st Sess. II-35 (1971).

20 See FWQA, Clean Water for the 1970's: A Status Report 5 (1970).

21 See Estuarine Study, supra note 9, at 264.

22 Hill, Statistics Can Becloud the Pollution Picture, N.Y. Times, Dec. 28, 1970, $\$ 1$, at 26 , col. 3 .

23 See Estuarine Study, supra note 9, at 264.

$24 I d$.

25 Id. 236; see 2 Federal Water Pollution Control Administration, The Cost of Clean Water 62 (1968).

26 In 1963 the industrial and municipal sectors were believed responsible for approximately equal amounts of organic wastes. 1963 Hearings, supra note 17 , at 15 (study by Division of Water Supply \& Pollution Control, U.S. Public Health Service). 
pected to reach sixty-five percent by $1989 .{ }^{27}$ Four major groups heading the list of industrial polluters-the organic chemical, primary metals, paper, and petroleum industries-account for over half the volume of wastes discharged into the waters. ${ }^{28}$ Rough data are available on the characteristics of the effuent associated with each industry, ${ }^{29}$ although, as indicated, knowledge of the wastes produced by individual plants remains largely a mystery, even to the plant manager.

Water pollutants are numerous and complex. In a 1969 report FWQA listed a total of fifty-one agents being introduced into the nation's waters as a result of industrial processes, a figure acknowledged to be but partially descriptive of the problem. ${ }^{30}$ The Manufacturing Chemists Association reported in 1965 that waterborne wastes were produced by more than 5000 separate chemical processes, ${ }^{31}$ and there is every indication that scores of new processes will be in operation within the next few years. Lack of information about the particulars in man-made water effluents has prompted scientists and lawyers to describe the characteristics of waste streams in terms of certain collective qualities, such as the weight of suspended solids (only some of which are settleable), or biological oxygen demand (BOD), a measure of the weight of dissolved oxygen consumed in the biological processes degrading organic matter. ${ }^{32}$

Industrial wastes degrade the quality of receiving waters by causing unpleasant tastes, odors, colors, excessive mineralization, salinity, and heat. Some compounds are highly toxic or potentially so. Of

27 See 16 Research Projects Aimed at Providing Closed Industrial Wastewater Systems to Abate Pollution, U.S. Dep't of the Interior News Release No. 27759, at 1 (Sept. 10, 1970).

28 See FWQA, Clean WATER for the 1970's: A Status Report 5 (1970). These four groups were responsible for $85 \%$ of the 14.2 trillion gallons of water used by manufacturing plants in 1964. ESTUARINE STUDY, supra note 9, at 236.

29 ESTUARINE STUDY, supra note 9, at 258-62.

30 See FWQA, Clean Water for the 1970's: A Status Report 5 (1970), citing FWQA, THE COST OF CLEAN WATER AND ITS ECoNomic IMPACT (1969). Among the compounds appearing in conventional effluents are:

metals such as iron, chromium, nickel, and copper; salts such as compounds of sodium, calcium, and magnesium; acids such as sulfuric and hydrochloric; petroleum wastes and brines; phenols; cyanides; sulfides; ammonia; toluene; blast furnace wastes; greases; pickling liquors; all sorts of suspended and dissolved solids and numerous other waste compounds.

House Comm. on Gov't Operations, The Critical Need for a National. Inventory of INDUStrial Wastes (Water Pollution Control aNd Abatement ), H.R. REP. No. 1579, 90th Cong., 2d Sess. 9 (1968).

31 Natronal Association of Manufacturers, Water in INdustry 58 (1965).

32 American Chemical Society, Cleaning Our Environment : The Chemical BASIS FOR ACTION 96 (1969). 
special complexity and toxicity are radiological wastes ${ }^{33}$ and pesticides. ${ }^{34}$ Hundreds of radioactive isotopes alone have been identified in waste effluents, ${ }^{35}$ and the effects of some are still unknown.

It is commonly asserted that technology is available to treat all of the undesirable characteristics of contaminated water. ${ }^{36}$ But this is not the case, as former Interior Secretary Hickel has warned: "Conventional treatment technology is often inadequate for treating many industrial wastes," and "55 new chemicals are developed each year by chemical and allied industries." 37 The DDT and mercury crises illustrate that traditional methods are incapable of combatting the continuing biological and chemical assault upon the nation's waters. A cadmium, arsenic, or polychlorinated biphenyl crisis may be around the corner. ${ }^{38}$ In short, industrial water pollution today poses complex, diverse, and constantly changing scientific and technological problems. ${ }^{39}$ An imaginative application of the Refuse Act offers one method for confronting this rapidly developing problem. The Refuse Act provides the best opportunity for an effective resolution of the problem because it affords the federal government significant veto powers over injections of foreign substances into navigable waterways.

\section{The Refuse Act}

The humble specifics of a nineteenth century statute are almost an insult to the sophisticated wastes of modern technology. Section 13 of the Refuse Act of 1899, in primitive absolutes, flatly prohibits discharging from a ship or shore installation into navigable waters of the United States "any refuse matter of any kind or description whatever other than that flowing from streets and sewers and passing therefrom in a

33 See Jornt Comm. on Atomic Energy, Selected Materials on Envtronmental Effects of Producing Power, 91st Cong., 1st Sess., pt. B, at 79-133 (1969).

34 See Rodgers, The Persistent Problem of the Persistent Pesticides: A Lesson in Envirommental Law, 70 CoLuM. L. Rev. 567 (1970); cf. Federal Insecticide, Fungicide, and Rodenticide Act, 7 U.S.C. \$§ 135-35k (1964).

35 Jornt Conim. on Atomic Energy, Selected Materials on Environmental Effects of Producing Power, 91st Cong., 1st Sess., pt. B, at 101-08 (1969).

36 See Estuarine Study, supra note 9, at 37; Comm. on Pollution, National Researce Counct, National Academy of Sciences, Pub. No. 1400, Waste Management and Control: A Report to the Federal Council for Scrence and TECHNOLOGY 177-78 (1966).

3716 Research Projects Aimed at Providing Closed Industrial Wastewater Systems to Abate Pollution, U.S. Dep't of the Interior News Release No. 27759, at 2 (Sept. 10, 1970).

38 See, e.g., N.Y. Times, Apr. 12, 1971, at 41, col. 3 (Further Oyster-Cadmium Study Urged.).

39 See generally, Hearings on the Adequacy of Technology for Pollution Abatement Before the Subcomm. on Science, Research, \& Development of the Honse Comm. on Science \& Astronautics, 89th Cong., 2d Sess. (1966). 
liquid state." 40 This section also forbids depositing "material of any kind in any place on the bank of any navigable water . . . where the same shall be liable to be washed into such navigable water . . . whereby navigation shall or may be impeded or obstructed." A proviso states that the Secretary of the Army "may permit the deposit of any material above mentioned in navigable waters, within limits to be defined under conditions to be prescribed by him." Related statutes delineate the authority of the Secretary of the Army to establish water dumping grounds for industrial wastes. ${ }^{41}$ Section 10 of the Refuse Act prohibits "the creation of any obstruction not affirmatively authorized by Congress, to the navigable capacity of any of the waters of the United States." 42 Also forbidden are the unauthorized construction of bridges, dams, and causeways in navigable waters, ${ }^{43}$ taking possession of works built by the United States, ${ }^{44}$ and obstruction of navigable waters by vessels and floating timber. ${ }^{45}$ Violations are misdemeanors punishable by a fine of not more than $\$ 2500$ nor less than $\$ 500$ or by imprisonment not to exceed one year. ${ }^{46}$ "In the discretion of the Court," reads the astonishing clause appended to the penalty provisions, "one-half of said fine [is] to be paid to the person or persons giving information which shall lead to conviction." 47 Though the legislation is unclear on the point, it is at least arguable that a separate violation would be found for each day of a continuing discharge. ${ }^{48}$

\section{A. The Revival of Section 13}

Recently, the Refuse Act has become a cause célebre for the environmental movement. Columnists speak of the rich booty awaiting

4033 U.S.C. $\$ 407$ (1964).

41 Id. $\$ 419$.

$42 I d$. $\$ 403$. This section also makes it unlawful to build any structure not conforming to plans "recommended by the Chief of Engineers and authorized by the Secretary of the Army." Id.

43 Id. $\$ 401$ (1964).

44 Id. $\$ 408$ (1964).

45 Id. $\$ 409$ (1964).

46 Id. $\$ \$ 406,411$ (1964).

47 Id. $\$ 411$ (1964).

48 The issue is whether a $\S 13$ discharge is an uninterrupted course of conduct constituting but a single offense for double jeopardy purposes. $C f$. Mones PENAI CODE $\$ 1.07$ (1) (e) (1962). A number of grounds-not the least of which is an occasional interruption caused by shutdown-support the conclusion that discharges over a period of several years constitute more than one violation. $C f$. Kirchheimer, The Act, The Offense and Double Jeopardy, 58 YAle L.J. 513, $539-42$ (1949).

Senator Theodore F. Stevens has introduced a bill that would make each day's violation of $\$ 13$ a separate offense and would raise the maximum fine per offense to $\$ 100,000$. S. 4103 , 91st Cong., 2d Sess. (1970). No action was taken during the 91 st Congress, however. 
informers on water polluters. ${ }^{49}$ Congressmen have prepared how-tocollect-the-reward instructions for interested constituents. ${ }^{50}$ Sporadic requests for prosecution, accompanied by demands for the bounty, have been filed with numerous United States Attorneys. ${ }^{\mathbf{1}}$ The stampede began in earnest with the release, in early 1970, of a report by the House Subcommittee on Conservation and Natural Resources detailing the specific features of the reward provisions of section 13 and recommending vigorous enforcement by federal officials and interested citizens. ${ }^{.2}$ Claims under the Act rapidly accumulated, ${ }^{53}$ and in September 1970 the subcommittee reported a flood of inquiries by citizens asking how they could help in the enforcement of the statute. ${ }^{54}$ Several actions have resulted in a recovery for the informer. ${ }^{55}$

Enforcement of the Refuse Act has become a crucial water pollution issue. As early as 1966 the Comptroller General reported wholesale violations of the Corps' permit provisions by firms dumping industrial solids into navigable waters. ${ }^{56}$ Recent renewed interest has led to further disclosures that the Corps has been but sporadically faithful in screening issuance of section 13 permits to industrial polluters. In August 1970 Representative Henry S. Reuss, Chairman of the House Subcommittee on Conservation and Natural Resources, released a 104 page document compiled by the Corps disclosing that current section 13 permits were held by only 266 of the thousands of stationary industrial

${ }^{49} C f$. Udall, Call for Inaction Raised by Justice Dept., Seattle Times, July 12, 1970, at A10, col. 4.

50 E.g., Circular from Henry S. Reuss, Chairman of the Subcomm. on Conservation and Natural Resources of the House Comm. on Gov't Operations, to Citizens Interested in Preventing Pollution and Enhancing the Quality of this Nation's Waters Through Citizen Action Aiding Enforcement of the 1899 Refuse Act, on file in Biddle Law Library, Univ. of Pa. Law School.

51 For example, on "Earth Day," Apr. 22, 1970, Congressman Michael J. Harrington announced that he was reporting 151 polluters "who have not even filed preliminary plans for pollution abatement with the [Massachusetts] Water Pollution Control Division." Harrington said he "would contribute any rewards to which he might become entitled to the state and federal water pollution control agencies." Congressman Michael J. Harrington Press Release No. 66 (Apr. 22, 1970).

52 House Comm. on Gov't Operations, Our Waters and Wetlands: How the Corps of Engineers Cain Help Prevent Their Destruction and Pollution, H.R. Rep. No. 917, 91st Cong., 2d Sess. (1970).

53 See, e.g., 2 CCH Clean AIR \& WATER News, No. 30, at 15 (July 22, 1970) (reporting that Congressmen Edward I. Koch of New York, Henry S. Reuss of Wisconsin, and Michael J. Harrington of Massachusetts, and a "group in Alabama" had made claims under the Refuse Act).

54 Staff of Subcomm. on Conservation \& Natural Resources of the House Comm. on Gov't Operations, 91 st Cong., 2d Sess., Qui Tam Actions and the 1899 Refuse Act: Cituzen lawsurts Agatnst Polluters of the Natron's Waterways iii (Comm. Print 1970) [hereinafter cited as Qui TAM Actions].

55 E.g. United States v. Transit-Mix Corp., No. 70-Cr-844 (S.D.N.Y. Dec. 11, 1970); Polikoff, The Interlake Affair, WAsHINGton Montery, Mar., 1971, at 7, 9.

56 General Accounting Office, Report to the Congress on Need for I proving Procedures to Ensure Compliance with Law Regarding Disposition of Industrial Waste Solids Into Navigable Waters (1966). 
sources presumably covered by the statute. ${ }^{57}$ The potential impact of corporate criminal liability was staggering. With this revival of interest in the Refuse Act have come opportunities to rethink and to modify the conditions to be imposed upon industries using the nation's waters as a refuse dump.

In the summer of 1970 the Corps of Engineers announced that industrial discharges into navigable waters would be subject to new regulations pursuant to section 13 permit procedures, ${ }^{58}$ a policy decision soon preempted by higher authority. On December 23 President Nixon promulgated an executive order ${ }^{59}$ directing the implementation of a permit program to enforce section 13. He declared, "To deal with those who are disregarding our pollution control laws, a swift and comprehensive enforcement mechanism is provided by this authority." 60 Proposed rules published concurrently by the Corps contained a public warning that widespread criminality would no longer be protected by an official tolerance policy. ${ }^{61}$

Now underway is a sweeping reassessment of governmental regulation of industrial water pollution. This Article explores the appropriate response to Refuse Act offenders and suggests steps which can be taken to assure that this period of the awesome reach of the law is not soon reduced to an optimistic interlude by the wholesale issuance of rubber-stamped permits. A closer examination of the statute will advance the analysis.

\section{B. Interpretation}

\section{The Meaning of Refuse}

Crucial to the application of the Refuse Act to control the quality of our water is the breadth assigned section 13's prohibition against

57 See Note, The Refuse Act of 1899: New Tasks for an Old Law, 22 Hastings L. REv. 782, 788 n.51 (1971).

58 Corps of Engineers Requirements for Permits for Industrial Discharges Into Navigable Waters, U.S. Army Corps of Engineers News Release, Seattle District (Aug. 4, 1970).

59 Exec. Order No. 11,574, 3 C.F.R. 188 (Supp. 1970).

60 Statement by the President Upon Signing an Executive Order Providing for the Establishment of a Federal Permit Program to Regulate the Discharge of Waste Into the Waters of the United States, 6 WeEkLy Comprilation of Presidential. DocUMENTS 1724 (1970).

61 Except as otherwise provided in the Refuse Act (33 U.S.C. 407), all discharges or deposits into the navigable waters of the United States or tributaries thereof are, in the absence of an appropriate Department of the Army permit, unlawful. The fact that official objection may not have yet been raised with respect to past or continuing discharges or deposits should not be interpreted as authority to discharge or deposit in the absence of an appropriate permit, and will not preclude the institution of legal proceedings in appropriate cases for violation of the provisions of the Refuse Act.

Permits for Discharge or Deposits into Navigable Waters, 35 Fed. Reg. 20005 (1970), revised and adopted, 36 Fed. Reg. 6565-66 (1971). 
depositing "any refuse matter of any kind or description whatever" into navigable waters or tributaries thereof. In United States v. Standard Oil Co., ${ }^{62}$ the Supreme Court refused to limit the word "refuse" to "substances lacking a pre-discharge value." 63 Holding that an accidental discharge into the St. Johns River of valuable aviation gasoline constituted the deposit of refuse, the Court said:

This case comes to us at a time in the Nation's history when there is greater concern than ever over pollution-one of the main threats to our free-flowing rivers and to our lakes as well. The crisis that we face in this respect would not, of course, warrant us in manufacturing offenses where Congress has not acted nor in stretching statutory language in a criminal field to meet strange conditions. But whatever may be said of the rule of strict construction it cannot provide a substitute for common sense, precedent, and legislative history. We cannot construe $\S 13$ of the Rivers and Harbors Act in a vacuum. ${ }^{64}$

"Oil is oil," said the Court, "and whether useable or not by industrial standards it has the same deleterious effect on waterways." ${ }^{25}$ That many of our environmental contaminants should be doing valuable service elsewhere did not prevent their condemnation as "refuse" when deposited in our waterways. ${ }^{66}$

Arguing that the meaning of the phrase "refuse matter" is "clear as a matter of ordinary English," ${ }^{67}$ and means waste, rubbish, trash, debris, and garbage, the dissenters pointedly emphasized the breadth of the majority's definition which embraced "all foreign substances and pollutants apart from those 'flowing from streets and sewers and passing therefrom in a liquid state' into the watercourse." 68 They agreed that valuable oil may damage the water environment but concluded that "Congress' purpose in enacting this anti-obstruction Act . . . appears quite plainly to be a desire to halt through the imposition of criminal penalties the depositing of obstructing refuse matter in rivers and harbors." ${ }^{69}$ Otherwise, observed Mr. Justice Harlan with alarm

62384 U.S. 224 (1966). See Tripp \& Hall, Federal Enforcement Under the Refuse Act of 1899, 35 Albany L. Rev. 60 (1970).

63384 U.S. at 228.

64 Id. at $225-26$.

$65 I d$. at 226.

66 See Comm. on Pollution, National Research Council, National Academy of Sciences, Pub. No. 1400, Waste Management and Control: A Report to the Federal Council for Scrence and Technology 35 (1966).

67384 U.S. at 234.

68384 U.S. at 230.

69 Id. at 233-34 (emphasis added). 
and insight, "dropping anything but pure water into a river would appear to be a federal misdemeanor." 70

Justifying its reading by finding that Congress had intended section 13 as a codification without change of several earlier acts which spoke in broader and more varied terms, the Court responded, "The philosophy of those antecedent laws seems to us to be clearly embodied in the present law." 71 Among these was an 1886 act making it unlawful to empty "any ballast, stone, slate, gravel, earth, slack, rubbish, wreck, filth, slabs, edgings, sawdust, slag, or cinders, or other refuse or mill-waste of any kind into New York Harbor . . . ."72 Another of these predecessor enactments was an 1888 statute, entitled in part "An act to prevent obstructive and injurious deposits within the harbor and adjacent waters of New York City," and which forbade the discharge of "refuse, dirt, ashes, cinders, mud, sand, dredgings, sludge, acid or any other matter of any kind, other than that flowing from the streets, sewers, and passing therefrom in a liquid state . . . " 73 An 1890 act made unlawful emptying into navigable waters the refuse detailed in the 1886 act "or other waste of any kind . . . which shall tend to impede or obstruct navigation ...." 74 An 1894 act prohibited deposits of essentially the same types of refuse barred from New York waters by the 1888 act into harbors and rivers for which Congress had appropriated money for improvements. ${ }^{75}$ In reviewing the earlier legislation, the Court in Standard Oil concluded, "The use of the term 'refuse' in the codification serves in the place of the lengthy list of enumerated substances found in the earlier Acts and the catch-all provision found in the Act of 1890." 76

A survey of state law at the turn of the century lends support to Standard Oil's expansive reading of the Refuse Act. ${ }^{77}$ New York City unequivocally adopted the test deemed extraordinary by Mr. Justice Harlan: it made criminal the dumping of anything but clean water into defined waterways. ${ }^{78}$ The generic term "refuse" was often linked with

$70 I d$. at 234.

71 Id. at 228.

72 Id. at 226-27 (quoting Act of August 5, 1886, ch. 929, §3, 24 Stat. 329).

$73 \mathrm{See}$ id. at 227 (emphasis by the Court deleted) (quoting Act of June 29, 1888, ch. $496, \S 1,25$ Stat. 209).

74 Id. (quoting Act of September 19, 1890, ch. 907, §6, 26 Stat. 453).

75 Id. (citing Act of August 18, 1894, ch. 299, §6, 28 Stat. 363).

$76 \mathrm{Id}$. at 228 .

77 See U.S. Geological Survey, Dep't of the Interior, A Review of The Laws Fordidding Poliution of Inland Waters in the United States, H.R. Doc. No. 741, 58th Cong., 2d Sess. (1904) [hereinafter cited as Water Pollution Review].

$78 \mathrm{New}$ York statutes of 1901 made it unlawful to throw anything whatever into the water supply of the city of New York. WATER Pollution REview, supra note 77, at 105. Section 1326 of the AnNotated Code of the General Statute Laws of THE STATE of MississIPPI (1892) made it a misdemeanor to "pollute any [navigable] 
specific industrial wastes in statutory prohibitions. ${ }^{79}$ It is true that the law of riparian rights generally tended to stress impairment of use as a criterion of relief, ${ }^{80}$ but respectable support can be found for the natural flow allocation theory, "a rather absolutist concept," which holds that all riparian owners "are entitled to have the stream flow past their land precisely as it was wont to do in the state of nature." 81 Unquestionably, a conventional reading of riparian rights law reflected little sympathy for those who disposed of wastes in public waters: "If the water is used for any other than farming or domestic purposes, it must be such a use as will not change the character of the water from its natural state or make it less useful to other owners. If the riparian owner cast sewage, filth, or waste material therein, he does it at his peril." 82

\section{Obstruction to Navigation}

Of even greater consequence than the expansive definition given the term "refuse" in Standard Oil was the Court's refusal to limit the term "refuse" to that which obstructed or threatened navigation. Pointing out that oil in rivers and harbors is "both a menace to navigation and a pollutant," 83 the Court found that the legislative history of the Refuse Act supported the proposition that the "serious injury" the Act was to remedy "was caused in part by obstacles that impeded navigation and in part by pollution . . . " 84 Dual grounding of a holding that could have been upheld on the "menace to navigation" theory alone clearly suggests that the Court is willing to uphold convictions for violation of the Refuse Act brought for either obstruction or pollution. The broad statement of the majority that " 'refuse' includes all foreign substances and pollutants" 85 must erase any doubt of the Court's meaning, particularly when contrasted to the minority's protest that

waters by putting therein the carcass of any dead animal, or any refuse or foul matter, or any matter or thing calculated to render the water thereof less fit for drink, or the sustenance of fish ...." WAter Pollution Review, supra note 77, at 32 .

79 North Dakota and Oklahoma anti-poliution statutes at the turn of the century referred to gas houses and factories. WATER PoLLUTION REviEw, supra note 77, at 33, 34. Ohio statutes specifically enumerated coal mines, coal-oil refineries, gas works and cheese factories. Id. 47. West Virginia laws mentioned slaughter-houses, butchers' establishments, packing houses, hotels, and taverns. Id. 55. The Vermont provisions referred to mills generally. $I d$. 111 .

80 See Ohrenschall \& Imhoff, Water Law's Double Environnent: How Water Law Doctrines Impede the Attainment of Environmental Enhancenent Goals, 5 LAND \& WATER I. REV. 259, 267-70 (1970).

81 J. Sax, Water Law, Planning and Polycy 1 (1968).

82 WAter Pollution Review, supra note 77, at 8.

83384 U.S. at 226.

84 Id. at 229.

$85 \mathrm{Id}$. at 230 . 
the relevant inquiry is not the admittedly important concerns of pollution control, but Congress' purpose in enacting this anti-obstruction Act, and that appears quite plainly to be a desire to halt through the imposition of criminal penalties the depositing of obstructing refuse matter in rivers and harbors. ${ }^{86}$

The Court's holding deeply disappointed industrial polluters. For example, in 1970 a witness representing the DuPont Corporation protested before the Senate Subcommittee on Air and Water Pollution that "the use of the archaic 1899 law is disruptive to the orderly improvement of water quality and provides propaganda to be used to undermine the effectiveness of the State and Federal programs . . . ." He maintained that the "control of navigational interferences" was the purpose of the Act and it should be so limited. ${ }^{87}$

Whether interference with navigation is essential to establishing a violation is crucial to the scope of the Act, for, after all, what is at stake is whether most major industrial water users in the United States will be forced to renegotiate their discharge and treatment policies to escape the sanctions of the criminal law. Standard Oil's rejection of the "interference with navigation" limitation is defensible if not compelling. To be sure, the central thrust of the 1899 legislation was to forbid a variety of obstructions to navigation. ${ }^{88}$ Nonetheless, the phrase "refuse matter of any kind or description whatever" is broad enough to include the sundry organic and inorganic chemicals, oils, acids, and sludges that are deposited by the billions of gallons daily into the nation's waterways. Only the second clause of section 13, making it unlawful "to deposit, or cause, suffer, or procure to be deposited material of any kind in any place on the bank of any navigable water," explicitly conditions criminality upon a finding that "navigation shall or may be impeded or obstructed." s9 Earlier statutes, of which the 1899 Act is a codification, specifically identified nonobstructing discharges, such as the acids mentioned in the 1888 act, ${ }^{90}$ and the mill wastes referred to in the 1886 act. ${ }^{31}$ The preamble to the 1888 act, moreover, expressed an intention to deal with both "obstructive and injurious deposits." 92

s6 Id. at 233-34.

87 Hearings on Water Pollution Before the Subcomnn. on Air \& Water Pollution of the Senate Comm. on Public Works, 91st Cong., 2d Sess., pt. 5, at 1647 (1970) (statement of Samuel Lenher, Vice President of E. I. DuPont de Nemours \& Co.) [hereinafter cited as 1970 Hearings].

8s See text accompanying notes $42-45$ supra; Note, The Refuse Act: Its Role Within the Scheme of Federal Water Quality Legislation, 46 N.Y.U.L. REv. 304, 306 n.21 (1971).

s9 33 U.S.C. $\$ 407$ (1964).

$90 I d$. $\$ 441$.

91 See Act of Aug. 5, 1886, ch. 929, §3, 24 Stat. 329.

9233 U.S.C. $\$ 441$ (1964). 
The legislative history of the 1899 Refuse Act also suggests that this earlier coverage was meant to be preserved in the codification. ${ }^{93}$

Notwithstanding the existence of some doubt as to the actual intent of the framers of the Refuse Act, important modern concerns about pollution control should be taken into account in interpreting the Refuse Act. Contrary to the narrow view taken by the dissenters in Standard Oil, it is a part of the judicial function to adapt old laws to new conditions and new concerns. Of course, a court cannot have license to read into a statute meaning which its words will not bear. But this problem does not arise in construing the Refuse Act to cover nonobstructing pollutants. The prohibitory words are not confined to obstructing matter. In enacting the Refuse Act, Congress was clearly concerned with the general condition of the waterways. Although the focus of attention at the time of enactment may have been on the specific problems created for navigation, a court today should look as well to other specific undesirable ramifications of allowing matter to be deposited in the waterways, whether or not Congress foresaw the particular new situation.

Standard Oil's conclusion that "refuse matter of any kind or description whatever" includes all those "foreign substances and polIutants" which may injure, obstruct, or offend was not unaugured in the case law. In construing section 13, the courts had condemned, for example, discharges of petroleum products, ${ }^{94}$ residue from a strip mine operation, ${ }^{95}$ and other nondescript industrial solids. ${ }^{96}$ The trend since Standard $O i l$ has also been to give an expansive reading to the meaning of refuse. ${ }^{97}$ In United States v. Florida Pozver and Light Co., ${ }^{98}$ the district court refused a preliminary injunction sought against a power plant discharging hot water. Although the court did not decide whether

93 United States v. Standard Oil Co., 384 U.S. 224, 227-28 (1966). Several contemporary state laws similarly forbade water pollution without regard to its obstructing potential. See note 78 sicpra.

94 E.g., United States v. Ballard Oil Co., 195 F.2d 369 (2d Cir. 1952).

95 See United States v. Bigan, 170 F. Supp. 219 (W.D. Pa. 1959), aff'd, 274 F.2d 729 (3d Cir. 1960).

${ }^{96}$ See United States v. Republic Steel Corp., 362 U.S. 482 (1960). See also Maier v. Publicker Commercial Alcohol Co., 62 F. Supp. 161 (E.D. Pa. 1945), aff'd per curian, 154 F.2d 1020 (3d Cir. 1946) (civil action for damages from dumping of grain residues from a distillery; violation of $\$ 13$ not sufficient for a private recovery); Warner-Quinlan Co. v. United States, 273 F. 503 (3d Cir. 1921) (dumping of fuel matter, sludge, black oil, and tar held violation of $1888 \mathrm{Act}$ ).

97 See United States v. Maplewood Poultry, 2 [Cases] BNA ENV. REP. 1646, 1647 (D. Me. June 10, 1971); United States v. Interlake Steel Corp., 297 F. Supp. 912 (N.D. I11. 1969).

98311 F. Supp. 1391 (S.D. Fla. 1970). Here the government requested a preliminary injunction against the dumping of heated water into Biscayne Bay. 
heated water is "refuse" under section 13 , it did not summarily reject the contention that it was, and it did repudiate the view that the provision is restricted to obstructing matter.99 Presumably, waste water having actual or potentially harmful effects on marine organisms would be a "foreign substance or pollutant" within the meaning of Standard Oil. ${ }^{100}$ Thus, to fall within the definition of "refuse" it does not appear to be essential that matter be added to the water, rather only that the water be affected. The generic ban on "refuse" should be read to condemn modern variations of the general problem at which the Refuse Act was aimed, of which thermal pollution is one. Just as the general proscriptions of the 1888 act were extended to oil discharges, which were not a problem at the time of enactment but later became a considerable nuisance, ${ }^{101}$ the Refuse Act prohibitions should be extended to include thermal pollution, and a fortiori acids, and radiological and chemical wastes liberated by modern manufacturing processes.

Whether partially treated wastes discharged into navigable waters qualify as "refuse" deserves mention. A central aim of water quality control is to bring the weight of the law to bear upon polluters' decisions concerning control technology and process change. Nevertheless, as a matter of prosecutorial discretion in a system of justice with limited resources, the generator of wastes who has minimized the toxicity of his output by resort to modern treatment methods will probably tend to be overlooked. This is especially true since the complete elimination of polluting compounds may be impossible, or at least economically unfeasible, under current technology. ${ }^{102}$ This route to leniency for the partial polluter, however, finds no support in the Refuse Act. The legislation, in its simplicity and single-mindedness, makes no exception for "treated refuse." In sum, the per se proscriptions of the Act should be viewed, as Justice Harlan (writing for the dissenters) anticipated

\section{$99 \mathrm{Id}$. at 1392 n.1.}

100 See text accompanying note 68 supra. For information on the biological effects of waste heat discharges, see Hearings on Thermal Pollution Before the Subcomm. on Air \& Water Pollution of the Sente Comm. on Public Works, 90th Cong., 2d Sess. passim (1968). The Corps of Engineers has adopted the position that the Refuse Act applies to heated water. Recently published regulations by the Corps of Engineers under the Refuse Act Permit Program declare:

Discharges or deposits of water at a temperature different from that of the navigable waterway or tributary into which the same will flow are considered to be discharges or deposits to which the Refuse Act is applicable.

36 Fed. Reg. 6565 (1971) (to be codified at 33 C.F.R. \$209.131(d) (1)). 101 See The Colombo, 42 F.2d 211 (2d Cir. 1930) (per curiam).

$102 \mathrm{See}$ U.S. Publtc Heatth Service, Community Water Supply Study: Significance of National Findings (1970).

We deceive ourselves if we assume that even the most complete and effective treatment of municipal and industrial wastes can ever remove all threats of water contamination.

Id. i (preface by Charles C. Johnson, Jr., Assistant Surgeon General). 
they would be in Standard Oil, to make criminal the dumping of anything but clean water of the same temperature into navigable waters. For industrial treatment purposes the objective must be essentially "clean water in, clean water out." This gives the federal government vast authority over what is deposited in our waters: it provides the opportunity for compelling advanced treatment or complete recycling of pollution pursuant to a reasonable timetable.

For years, the Corps consistently interpreted the Refuse Act as applying only to deposits that created obstructions. The view has some support ${ }^{103}$ but recent legislation, ${ }^{104}$ judicial decisions, ${ }^{105}$ congressional committee reports, ${ }^{106}$ and public pressure eroded the Corps' determined commitment to enforce the Refuse Act only in the interests of navigation. Finally in May 1970 the Corps announced "sweeping changes" in its regulations, emphasizing that it was "no longer concerned only with the impact which a proposed project may have on navigation." 107

103 Most obvious is the proviso of $\$ 13$ declaring " $[t]$ hat the Secretary of the Army, whenever in the judgment of the Chief of Engineers anchorage and navigation will not be injured thereby, may permit the deposit of any material above mentioned in navigable waters ...." It could also be said that the Corps was able to achieve an internal consistency in $\$ 13$ by reading the explicit obstruction requirement of the indirect discharge clause into the direct discharge clause.

Another explanation for the Corps' rejection of the anti-pollution potential of $\$ 13$ appears in current regulations which provide:

"[Section 13] authorizes the Secretary of the Army to permit the deposit of refuse matter in navigable waters, whenever in the judgment of the Chief of Engineers anchorage and navigation will not be injured thereby . . . . Although the Department has exercised this authority from time to time, it is considered preferable to act under Section 4 of the River and Harbor Act of March 3, 1905 ...."

33 C.F.R. 209.200(e) (2) (1971) (emphasis added). Mysteriously, then, permission to deposit refuse under $\$ 13$ was equated with permission under a statute passed six years later expressly for the purpose of allowing the Corps to establish dumping grounds for sludge dredgings and other refuse. The language perpetuating the confusion was $\$ 13$ 's definition of "refuse matter of any kind or description," transported into the 1905 statute, which, by its terms, authorized the Secretary to permit offshore dumping of "refuse materials of every kind or description, whenever in his judgment such regulations are required in the interest of navigation." 33 U.S.C. $\$ 419$ (1964). It was easy for the Corps to read the 1905 statute's obstruction to navigation limit into $\S 13$ of the earlier statute.

104 See Fish and Wildlife Coordination Act, 16 U.S.C. $\$ \S 661-666(c)$ (1964), as amended, 16 U.S.C. $\$ 662$ (d) (Supp. V, 1970); National Environmental Policy Act of 1969, 42 U.S.C. $\$ \$ 4331-35,4341-47$ (Supp. V, 1970) ; Water Quality Improvement Act of 1970,33 U.S.C.A. $\$ \$ 1152,1155,1156,1158,1160-75(1970)$, antending Federal Water Pollution Control Act, 33 U.S.C. $\$ \$ 466-66(\mathrm{n})(1964)$, as amended, 33 U.S.C. $\$ \$ 466-66(n)$ (Supp. V, 1970).

105 See Zabel v. Tabb, 430 F.2d 199 (5th Cir. 1970), cert. denied, 401 U.S. 910 (1971) ; cf. Citizens Comm. for the Hudson Valley v. Volpe, 425 F.2d 97 (2d Cir. 1970), cert. denied, 400 U.S. 949 (1970).

106 E.g., House Comm. on Gov't Operatrons, Our Waters and Wetrands: How the Corps of Engrnerers Can Hielp Prevent Their Destruction and Pollutron, H.R. ReP. No. 917, 91st Cong., 2d Sess. (1970); House Comm. oN Gov't Operations, The Permit for landfil in Hunting Creek: A Debacle in ConSERVAtion, H.R. REP. No. 113, 91st Cong., 1st Sess. (1969) [hereinafter cited as Hunting Creek Report].

107 Corps of Engineers Revises Permit Regulations, U.S. Army Corps of Engineers Press Release, Seattle District (May 19, 1970). 
The new policies now are in the process of explication and implementation, under the leadership of the White House and the Council on Environmental Quality. A review of the Corps' performance, presented elsewhere in this Article, ${ }^{108}$ suggests that the legal biases of the past may have an impact on any future institutional commitment to enforce the 1899 statute ${ }^{109}$ against industrial polluters. It is questionable whether an agency that for years insisted that it was concerned only with navigation and is organized, funded, staffed, and equipped to deal with navigation can be expected to turn its considerable energies and resources to curbing the assault of industrial pollution.

\section{The Sewage Exception}

The important exclusion from coverage in section 13 of the 1899 Act is that for discharges of refuse "flowing from streets and sewers and passing therefrom in a liquid state, into any navigable water . . . ." This reservation was explored briefly in United States $v$. Republic Steel Corp. ${ }^{110}$ a case in which the federal government sought to enjoin several steel companies from discharging wastes into the Calumet River without obtaining a permit from the Corps of Engineers. The Court rejected the argument that these discharges were excused by the statute because they had flowed from the companies' sewers into the river in a liquid state. ${ }^{111}$ In interpreting the exception, Mr. Justice Douglas cryptically concluded that:

The materials carried here are 'industrial solids,' as the District Court found. The particles creating the present obstruction were in suspension, not in solution. Articles in suspension, such as organic matter in sewage, may undergo chemical change. Others settle out. All matter in suspension is not saved by the exception clause in $\S 13$. Refuse flowing from 'sewers' in a 'liquid state' means to us 'sewage.' . . . The fact that discharges from streets and sewers may contain some articles in suspension that settle out and potentially impair navigability is no reason for ts to enlarge the group to include these industrial discharges. ${ }^{112}$

In dissent, Mr. Justice Harlan disagreed with both conclusions, strongly challenging the Court's decision to differentiate between industrial

108 See text accompanying notes 261-312 infra.

10933 U.S.C. $\$ 407$ (1964).

110362 U.S. 482 (1960).

111 Id. at $489-90$.

$112 I d$. at $490-91$. 
and domestic refuse and particles in suspension from those in solution. He would have excused all nonobstructing wastes that are piped into navigable waters. ${ }^{113}$

The legislative motive for the sewage exception is obscure. ${ }^{114}$ Unquestionably, Mr. Justice Douglas' distinction between matters in suspension and in solution creates some embarrassment since, as he confessed, discharges from exempted domestic sewers also tend to settle out to create an obstruction. The majority interpretation also opened the door to the argument that industrial wastes in solution are exempted if they flow from a sewer in a liquid state. A more viable explanation for the enactment of the sewage exception would be to view it as a practical concession to the then recently initiated public efforts to handle the waste disposal problem in the face of widespread statutory bans against discharging refuse of any sort into the water. In 1898, for example, Mississippi amended its criminal statute forbidding obstruction and pollution to provide that: "[T]his act shall not be construed as to prevent any city or town in this State from constructing sewers so as to empty into any navigable streams of water in this state." 115 Under this view, the sewage exception in the 1899 federal Refuse Act was designed to differentiate locally authorized from unauthorized discharges. By excepting refuse "flowing from streets and sewers . . . in a liquid state," Congress expressed awareness of the construction of public sewers, taking cognizance of the practice of the day of combining storm and sanitary sewers. ${ }^{116}$ The important point was not that waste made it through the system in a "liquid state," but rather that local authorities had some control over who connected to a sewer system. It could be justifiably assumed that industrial or municipal wastes flowing from sewers had been identified and the disposal endorsed by sewage officials. The purpose of section 13, then, would be to authorize the Corps to approve those discharges not disposed of through a municipal system.

113 Id. at 506.

114 See id. at 506 n.26.

115 WATER Pollution REviEW, supra note 77, at 32. In 1899 New Jersey's broad prohibitions against water pollution included a similar proviso:

That this section shall not be held to apply to any city, town, borough, township or other municipality of this State which, at the date of the passage of this act, has a public sewer or system of sewers, drain or system of drains, legally constructed under municipal or township authority, discharging its drainage or sewage into any ... river, brook, stream, lake, pond, well, spring or other reservoir ....

$I d .71$.

116 See F. Graham, Disaster By Default $37-38$ (1966). 


\section{Critique of Section 13}

As now broadly interpreted by the courts section 13 draws three uncomfortable lines. The separate treatment of refuse directly discharged into navigable waters from that deposited on land and ultimately "washing" into the water is scientifically indefensible, assuming a finding of culpability. The limitation of the Act to discharges into the "navigable waters of the United States" ignores equally reprehensible contamination taking place elsewhere and does not seem constitutionally compelled. The sewage exception is a gaping invitation to circumvention by many industrial polluters.

Contamination of bodies of water by runoff or leaching would appear to be no less a threat to the public interest than is contamination by direct discharge. The controlling question should be the potential effect upon water quality. At least one court, ${ }^{117}$ in derogation of the requirement that indirect discharges on shore must be obstructing, has concluded that the direct discharge clause covers deposits on land. The case held that oil dumped onto the land which flowed into the water "by gravity alone" was proscribed without regard to the obstruction requirement. At the same time, however, the court acknowledged the second clause of section 13 by noting that "there may be cases where the defense of remoteness would be available. . . ."118

Conditioning liability under the Act on lawyer's notions of remoteness is but a reformulation and blurring of the inescapable statutory distinction between direct discharges and indirect, on-shore discharges. The distinction ignores basic principles of hydrologic cycles. ${ }^{119}$ Of scientific importance are what the ecologist calls interface factors, such as the exchanges that occur between bodies of water, including drainage from the land. ${ }^{20}$ That the Refuse Act ignores scientific realities is a fundamental weakness.

Deep-well injection is one presently popular and relatively cheap method of postponing noxious-waste disposal decisions. ${ }^{121}$ Already, instances of contamination of ground water have been identified. ${ }^{122}$

117 United States v. Esso Standard Oil Co., 375 F.2d 621 (3d Cir. 1967).

$118 \mathrm{Id}$. at 623. This judicial interpretation has been incorporated into the Corps' Refuse Act Permit Program regulations. 36 Fed. Reg. 6565 (1971) (to be codified at 33 C.F.R. $\$ 209.131$ (d) (2) (v)).

110 See Estuarine Study, sipra note 9, at 574-75.

$120 \mathrm{Id}$.

121 A. Piper, Disposal of Liquid Wastes by Injection Underground-Neither Myth nor Millenium, U.S. Geological Survey Circular No. 631 (1969); D. Warner, Deep-Well Injection of Liquid Waste, U.S. Public Health Service Pub. No. 999-WP21 (1965) (revised and reprinted August 1967).

122 See N. Perlmutter, et al., Dispersal of Plating Wastes and Sewage Contaminants in Ground Water and Surface Water, South Farmingdale Massapequa Area, 
Serious reservations about the practice have been dutifully expressed by FWQA officials. ${ }^{123}$ More exposés of, and controversy over, the consequences-which range from pollution of drinking water supplies ${ }^{124}$ to possible contribution to earthquakes ${ }^{125}$ - can be expected. The harm to waters attributable to these disposal techniques, however, is beyond the reach of section 13 .

The "navigable waters of the United States" ${ }^{126}$ are assailed from the sea as well as from the land. One manifestation of the prevailing disposal mentality is the assumption that nerve gas will disappear if dumped far enough out. ${ }^{\mathbf{1 2 7}}$ The general practice of port authorities throughout the country requires ships to pump oil wastes into shore collection facilities, but then authorizes barging the wastes to sea for discharge beyond the fifty-mile limit. ${ }^{128}$ The present national administration has questioned the wisdom of treating the ocean as an inexhaustible disposal site. ${ }^{129}$ The Corps of Engineers' cavalier issuance of industrial dumping permits has come under bitter attack. ${ }^{130}$ But al-

Nassau County, New York, U.S. Geological Survey Water Supply Paper 1879-G (1970), summarized in 2 CCH CLEAN AIR \& WATER NEWs, No. 37, at 5 (Sept. 10, 1970).

123 E.g., Remarks by David Dominick, Comm'r, FWQA, U.S. Dep't of Interior News Release No. 28927 (Sept. 11, 1970).

124 N. Perlmutter, supra note 122 , at 5.

125 R. McCarthy, The Ultmate Folly 100-01 (1969).

126 The meaning of "navigable waters" under $\$ 13$ is a question for the judiciary since no definition is set forth in the Refuse Act. The generally cited definition is to be found in the leading case of The Daniel Ball, 77 U.S. (10 Wall.) 557 (1871):

Those rivers must be regarded as public navigable rivers in law which are navigable in fact. And they are navigable in fact when they are used, or are susceptible of being used, in their ordinary condition, as highways for commerce, over which trade and travel are or may be conducted in the customary modes of trade and travel on water.

Id. at 563. A narrower definition can be found in the Oil Pollution Act, 1924: "coastal navigable waters of the United States" are "all portions of the sea within the territorial jurisdiction of the United States, and all inland waters navigable in fact in which the tide ebbs and flows..." Act of June 7, 1924, ch. 316, \$2(c), 43 Stat. 605 , amended, Clean Water Restoration Act of 1966, Pub. L. No 89-753, \$211 (a), 80 Stat. 1253, repealed by Water Quality Improvement Act of 1970, Pub. L. No. $91-224, \S 108,84$ Stat. 113 .

For a summary of differing interpretations of "navigability" in various contexts, see Johnson \& Austin, Recreational Rights and Titles to Beds on Western Lakes and Streams, 7 NAT. REs. J. 1, 4-33 (1967).

127 Rodgers, Nerve Gas to the Northwest and Beyond, 1 ENvironMENTAL LeTters 111 (1971).

128 For some details on current oil disposal practices, see Hearings on Oil Shedge Dumping Off the Florida Coast Before the Subcomm. on Air \& Water Pollution of the Senate Comm. on Public Works, 91st Cong., 2d Sess. passin (1970). (1970).

129 Council on Environmental Quality, Ocean Dumping: A Natronal Policy

${ }^{130}$ E.g., Hearings on Resource Recovery Act of 1969 Before the Subcomm. on Air \& Water Pollution of the Senate Comm. on Public Works, 91st Cong., 2d Sess., pt. 5, at 2262-68 (1970) (testimony of Senator Williams) [hereinafter cited as Resource Hearings]. 
though further controversy impends, the Refuse Act is of no assistance in resolving these discharges beyond our "navigable" waters.

If section 13 were read to excuse all discharges which make their way into the water through public sewer systems, many polluting substances unaffected by conventional secondary treatment would be overlooked. ${ }^{131}$ Exotic and dangerous metals like lead, cadmium, and arsenic, and other proven pollutants such as the phosphates in detergents, may not be rendered significantly less harmful by the primary or secondary treatment to which they are sometimes subjected. ${ }^{132}$ The Montrose Chemical Corporation and the Los Angeles County Sanitation District have recently been parties in a lawsuit alleging that the defendants discharged and authorized the discharge, respectively, of DDT compounds into and through the public sewer system, and ultimately into the coastal waters of Santa Monica Bay. ${ }^{133}$ The litigation raised the issue whether under the Refuse Act a toxic industrial effluent passing through a municipal sewer system is within the statutory exception for refuse "flowing from streets and sewers and passing therefrom in a liquid state." It also posed the question whether the mere acceptance of an effluent by a municipal system should result in an automatic exemption from compliance with the federal Refuse Act. A case could be made that the federal incorporation of the municipal judgment as a measure of the breadth of the sewage exception assumes, first, compliance by the discharger with local sewer regulations and, second, that those regulations are compatible with the broad objectives of the Refuse Act. Regardless of the ultimate construction given to the exception, it is clear that putting wastes into a sewer system does not guarantee that they will be rendered harmless.

The recent revival of the Refuse Act will put greater pressure on municipal disposal authorities as industries seek to connect to municipal systems to avoid the federal criminal law. Sewage authorities across the nation must give renewed attention to defining the circumstances in which industries should be allowed to connect to municipal sewer systems. Some wastes are barred in some systems altogether; ${ }^{134}$ others

131 The Nixon administration reads the Refuse Act as being generally inapplicable to all municipal discharges. Statement by the President, supra note 60 , at 1725 ; see 36 Fed. Reg. 6565 (1971) (to be codified at 33 C.F.R. $\$ 209.131$ (d) (2) (i)).

132 E.g., 1970 Hearings, supra note 87, pt. 4, at 1384-85 (testimony of Dr. Ernest E. Angino).

133 Environmental Defense Fund v. Montrose Chemical Corp., Civ. No. 70-2389 ALS (M.D. Cal. Oct. 22, 1970) (dismissed as moot on June 17, 1971, after defendant ceased all discharge and began to dispose of the wastes at a dry land fill). (The author was co-counsel in this case.)

134 E.g., Municipality of Metropolitan Seattle, Wash. Resolution No. 610, Regarding the Control and Disposal of Industrial Waste Into the Metropolitan Sewage System (undated) ; Los Angeles County, Cal., Sanitation Districts, Policy Governing Use of District Trunk Sewers (1961). 
must be specially treated before they can be introduced into a system; all should be subjected to user charges. As the General Accounting Office has documented, the growing trend toward the treatment of industrial wastes in joint municipal-industrial plants may well mean that costs presently borne by industry alone will be assumed by the public under the federal authority to grant assistance to municipalities for construction of treatment plants. ${ }^{135}$ The Nader Task Force has uncovered additional evidence of the use of federal construction grants to subsidize industrial waste treatment. ${ }^{136}$

Despite legitimate and illegitimate pressures to direct industrial wastes into municipal systems, substantial segregation of wastes will continue in the foreseeable future. Industrial effluents may be barred from municipal systems for technological, financial, or geographical reasons. Industries denied acceptance by local authorities will discharge a significant volume of waste, before or after treatment, directly into the navigable waters and thus within the jurisdiction of the Corps. Negotiations under the Refuse Act, then, will be essential to doing business.

\section{The Definition of Pollution: Philosophy of the Refuse Acr}

\section{A. Pollution as a Relative Thing}

Contrary to the flat negatives of the Refuse Act, industrial interests traditionally have viewed "pollution" as a "relative thing." In the words of one industry spokesman: "Pollution is the discharge of material that unreasonably impairs the quality of water for maximum beneficial use in the overall public interest." 137 According to the National Association of Manufacturers, "This definition of pollution hinges on the word 'unreasonable.' Economic, sociological and political factors will inevitably influence any attempt to agree upon an interpretation." 138

135 Comptroller General, Report to the Congress, Federal Grants Awarded for Constructing Waste Treatarent Faciltties Which Benefit Industrial Users (1970).

136 NADER REPORT, supra note 8, ch. XVII, at 1-14.

1371963 Hearings, supra note 17, pt. 1A, at 742 (testimony of Richard D. Hoak on behalf of the American Iron \& Steel Institute).

138 National Association of Manufacturers, Water in Industry 22 (1965). This "relative" definition of pollution has been used as a basis for objecting to the request for waste discharge data useful in a regulatory scheme employing effluent standards. As one witness stated before a congressional committee in 1963:

The fact that there has been an almost universal objection by industry to 
So, too, the subject of water pollution from this point of view must be considered with respect to the receiving body of water-its size, flow, and the uses to which it is put. The volume and content of the effuent of a point source is largely irrelevant to this overall inquiry.

A basic conflict of legal philosophies is apparent between advocates of this position and those who are anxious to minimize any impact of discharge. It is, in substance, a repetition of the debate over stream standards ${ }^{139}$ or effluent standards, or of the air pollution controversies between the advocates of emission standards and the samplers of the ambient air. Fundamentally, the competing schools disagree on the economics of how much should be spent to secure control. But, the economic parameters (especially the external costs) of the debate being rarely susceptible to precise measurement, the disagreement of the two schools most frequently manifests itself with regard to the legal procedures for determining whether the discharge of foreign matter into the water should be forbidden.

The "relative" view of water pollution has many implications. It assumes a free use of water for waste disposal up to a point of "unreasonableness," however legally defined, and that the enforcement authority has the burden of proving that discharges harm marine resources or are deleterious to other water uses. ${ }^{140}$ It views the research obligation as largely a governmental responsibility. It insists that enforcement is a particularly local concern because the unique characteristics of the receiving water, the economics of the discharging plant, and even the prevailing political tolerance level, are crucial to any decisions to compel treatment or process change. The rhetoric of the "relativists" often views effluent standards as "treatment for treatment's sake" and condemns the proponents of these standards as alarmists. The position

supply data to the Public Health Service should alert this committee to the possibility that something is wrong. ...

Many state agency personnel agree with industry that the Public Health Service approach to measuring pollution and pollution abatement by the summation of waste load discharges and/or money spent is faulty. The subject of water pollution must be considered with respect to the receiving body of water-its size, flow, character, self-purification capacity, and use.

1963 Hearings, supra note 17, pt. 1B, at 1393-94 (statement of John E. Kinney, Sanitary Engineering Consultant, Ann Arbor, Mich.).

139 See, e.g., Dunkelberger \& Phillpes, Federal-State Relationships in the Adoption of Water Quality Standards Under the Federal Water Pollution Control Act, 2 Nat. REs. Law. 47 (1969). For a general economic defense of the stream standards approach to regulating water pollution, see Roberts, River Basin Authorities: $A N a-$ tional Solution to Water Pollution, 83 HARV. L. REv. 1527, 1542-44 (1970).

140 See Krier, Environmental Litigation and the Burden of Proof: Some Comments and Suggestions, in CONSERVATION FOUNDATION, CONFERENCE ON LAW AND THE ENVIrONAIENT (1969). 
is based, in short, upon a series of assumptions incompatible with the "no discharge" prohibitions of the Refuse Act.

This position, nevertheless, still dominates regulation in the water pollution world. The Federal Water Pollution Control Act assumes that waste disposal is a fundamental water use. ${ }^{141}$ The federal government premises its enforcement program on local control ${ }^{142}$ and accepts responsibility for proving damage from discharges. ${ }^{143}$ It has assumed a large share of the burden of developing industrial pollution control technology. ${ }^{144}$ And federal officials have taken up the rhetoric of "no treatment for treatment's sake." 145 Hopefully, the recent discovery of the Refuse Act reflects a change in this attitude.

\section{B. The Changing Regulatory Framework}

Early deviations from the established ground rules of pollution regulation were either faint promises of a better world or heresies to be suppressed, depending upon one's point of view. The most notable departure from the regulatory philosophy premised upon industry's "relative" concepts came from the federal government in 1967 with the issuance of guidelines for approval of standards in state water quality plans. ${ }^{146}$ The guidelines included provisions safeguarding high quality waters against degradation, ${ }^{147}$ disapproving state standards designating a stream for the "principal purpose of transporting wastes," 148 and, with limited exceptions, requiring all wastes "to receive the best practicable treatment or control" prior to discharge. ${ }^{149}$ Nice sentiments, no action.

141 The Act does not prohibit the use of water for waste disposal but instead authorizes the establishment of water quality standards. 33 U.S.C.A. $\$ 1160$ (c) (3) (1970).

142 See id. $\$ 1160(\mathrm{~b})$.

143 See id. $\$ 1160$ (c) (5).

144 See id. $\$ \S 1155,1156$.

145 For example, James M. Quigley, then Assistant Secretary, Dep't of Health, Education and Welfare, and now a vice president of U.S. Plywood-Champion Papers, Inc., expressed the hope that a "formula" definition would never be given the term "pollution," because he viewed it as a "relative question." 1963 Hearings, supra note 17 , pt. $1 \mathrm{~A}$, at 55 .

146 federal Pollution Control Administration, U.S. Dep't of the Intertor, GUIDELINES FOR ESTABLISHING WATER QUALITY STANDARDS FOR INTERSTATE WATERS, in Hearings on Activities of the Federal Water Pollution Control Administration Water Quality Standards (Water Pollution 1967) Before the Subcomm. on Air \& Water Pollution of the Senate Comm. on Public Works, 90th Cong., 1st Sess., pt. 2, at 658-60 (1967) [hereinafter cited as GuIDELINEs].

147 Id. 659 (nos. 1,5 ).

148 Id. (no. 2).

149 Id. 660 (no. 8). 
The guidelines have been revised, construed away, and flouted, most notably by FWQA's approval of state standards incompatible with articulated federal policy. ${ }^{150}$

All of this is changing. For the first time the Congress, in passing the Water Quality Improvement Act of 1970, imposed on polluters a modified strict liability for the clean-up costs of oil discharges. ${ }^{151}$ The President also is authorized by this Act to direct the removal of other discharged substances which he may designate as pollution hazards. ${ }^{162}$ Of greater significance-although the contours of the commitment remain obscure-is the decision of the administration to back legislation that would authorize effluent standards. ${ }^{153}$ That the Government is finally attempting to discover what is going into the water is further demonstrated by the commitment of EPA to undertake a voluntary water wastes inventory. Effluent disclosure obligations of the new permit program confirm a similar trend. EPA's current emphasis upon the development of closed recycling systems for wastes and water reuse is explicitly premised upon a policy of elimination of industrial wastes. ${ }^{154}$ The once unrealistic and uneconomical total-treatment objectives implicit in the Refuse Act are gaining a new currency in water pollution regulation circles.

For implementation of an "absolutist" definition of pollution, however, no legal development in the water pollution field can compare with the potential impact of a revived Refuse Act. Rationalization about "reasonable" amounts of pollution is not easily reconciled with a statute which declares it a crime to dump "refuse of any kind or description whatever" into navigable waters. The engineering and ecological ideal

150 For details of the rout, see NADER REPORT, supra note 8 , ch. XIV. On its extent, see Dunkelberger, The Federal Government's Role in Regulating Water Pollution Under the Federal Water Quality Act of 1965, 3 Nat. Res. LAw. 3, 11-17 (1970).

151 Water Quality Improvement Act of 1970 § 102, 33 U.S.C.A. §1161(f) (1970).

15233 U.S.C.A. \$1162 (1970).

153 See The President's Remarks Upon Transmitting His Message on Environmental Quality to the Congress, 6 WeEkLY ComprLatron of PREsIDENTIAL DocoMIENTS 158 (1970).

154

Such closed systems hold the promise of an ultimate solution in that they would abolish the discharge of polluted wastes to our waterways. The Nation's industries are the largest users of water and a major factor in the continuing rise of water pollution. Research that could eliminate the discharge of industrial wastes is one obvious approach in seeking solutions to our water pollution problems.

16 Research Projects Aimed at Providing Closed Industrial Wastewater Systems to Abate Pollution, U.S. Dep't of the Interior News Release No. 27759 (Sept. 10, 1970) (quoting Secretary Hickel). The Federal Water Quality Administration has awarded $\$ 4,225,572$ in grants directly to industry to support research and demonstration projects that would create closed recycling systems for wastes and water reuse. Id. 
of completely closed recycling systems for industrial water use has a strong legal ally in the simple proscriptions of the Refuse Act. The added rumor that a private citizen can collect a reward for reporting violators assures that the regulatory potential of the Act will be thoroughly tested. What the citizen can and should be allowed to do, however, deserves careful inquiry.

\section{The Enforcement of the Refuse Act}

\section{A. The Citizen and Section 13}

Enough has been said to suggest that the lack of knowledge about industrial pollution requires that the legal system encourage the informer. Undoubtedly, the sailboater, the university biology student, and the disgusted union member should be prompted to forward information they uncover to state pollution control agencies and to the United States Attorney for possible prosecution under the Refuse Act. But the question recently raised is whether a private citizen may pursue legal initiatives on his own. Much has been written about the legal theories which may prove useful to the citizen as plaintiff in water pollution litigation. ${ }^{155}$ Senate Commerce Committee hearings have been held; ${ }^{156}$ Michigan has enacted a law providing citizen standing; ${ }^{157}$ comparable measures are being debated elsewhere. ${ }^{158}$ Congressional authorization of citizen actions to enforce air quality standards no doubt will reinforce the pressures for a similar remedy against water polluters. ${ }^{159}$

The question about the Refuse Act that has received the greatest public attention-but, it is submitted deserves the least-is whether it provides a private remedy in the form of a qui tam action for a share of the penalty. Section 16 declares that, upon conviction for violation of the Act, the defendant

155 E.g., Hines, Nor Any Drop to Drink: Public Regulation of Water Quality, 52 Iowa L. Rev. 186, 196-201 (1966) ; Note, Private Remedies for Water Pollution, 70 Colum. L. REv. 734 (1970) ; Note, Water Quality Standards in Private Nuisance Actions, 79 YALE L.J. 102 (1969); Comment, The Refuse Act of 1899: Its Scope and Role in Control of Water Pollution, 58 CaLIF. L. Rev. 1444 (1970).

156 Hearings on S. 3575 Before the Subcomm. on Energy, Natural Resonurces \& the Environment of the Senate Comm. on Commerce, 91st Cong., 2d Sess., Ser. 80 (1970) [hereinafter cited as S. 3575 Hearings]. Hearings were held again in 1971. 1 [Current Developments] BNA ENv. Rep. 1435 (Apr. 23, 1971).

157 Mrch. Comp. LAws ANN. \$§691.1201-07 (Supp. 1971).

158 In Washington, for example, a bill expanding environmental remedies was introduced in the 1971 session of the state legislature. S.B. 560, 42d Reg. Sess. (1971).

159 Act of Dec. 31, 1970, Pub. L. No. 91-604, \$12(a), 84 Stat. 1706-07, amending 42 U.S.C. $\$ \$ 1857 i-l$ (Supp. V, 1970). For an explanation of the rationale of the citizen suit provision, see SENATE COMM. ON PUBLIC WORKS, NATIONAL AIR QUality Standards Act of 1970, S. Rep. No. 1196, 91st Cong., 2d Sess. 36-39 (1970). 
shall be punished by a fine not exceeding $\$ 2500$ nor less than $\$ 500$, or by imprisonment . . . for not less than thirty days nor more than one year, or by both such fine and imprisonment, in the discretion of the court, one-half of said fine to be paid to the person or persons giving information which shall lead to conviction. ${ }^{160}$

These words lend little support to the popular fervor that has been generated. One cannot amass vast riches by merely mailing a list of the neighborhood polluters to the local United States Attorney.

\section{Qui Tam Vel Non}

According to Blackstone, "Sometimes one part [of a civil recovery] is given to the king, to the poor, or to some public use, and the other part to the informer or prosecutor: and then the suit is called a qui tam action, because it is brought by a person "qui tam pro domino rege, etc. quam pro se ipso in hac parte sequitur." 161 He mentioned another category of cases which "are usually brought upon penal statutes, which inflict a penalty upon conviction of the offender, one part to the use of the king, and another to the use of the informer, and are a sort of qui tam actions, . . . only carried on by a criminal instead of a civil process . . . "162 Federal statutes provide in a variety of ways for utilizing the efforts of private citizens to enforce the law. Some say that "any person" may bring suit to enforce their provisions. ${ }^{163}$ Others appear to condition payment to an informer upon a successful conviction. ${ }^{164}$ And some in this latter category grant the trial judge discretion to determine whether the informant will share in the fine. ${ }^{165}$ Whether the informer can sue or must rely upon the United States Attorney is decisive in determining the reach of the 1899 Act penalty provisions.

In March of 1970 a subcommittee of the House Committee on Government Operations enthusiastically observed:

The Supreme Court has ruled that where a statute provides for a reward to the informer, the statute authorizes him, if the Government has not previously instituted a prosecution against the violator, to institute his own suit in the name of

16033 U.S.C. $\$ 411$ (1964).

1613 W. Blackstone, Comadentaries *161-62.

1024 W. Blackstone, Commentaries $* 308$.

163 E.g., 31 U.S.C. $\$ 232$ (B) (1964) (informing about fraud on the government).

164 E.g., 18 U.S.C. $\$ 962$ (1964) (arming a vessel against a friendly nation); 26 U.S.C. $\$ 7263$ (b) (1964) (recovery for information concerning cotton future frauds).

16521 U.S.C. $\$ 183$ (1964) (narcotics informers); 26 U.S.C. $\$ 7214$ (a) (1964) (informing about unlawful acts of revenue agents). 
the United States (a qui tam action) to collect his moiety of the penalty. ${ }^{106}$

The cases cited in support of this proposition, however, do not go so far. One arose under a statute which specifically authorized a suit to be brought "by any person." 167 Another held that a statute of limitations on penal actions barred an action in debt under an act "to prohibit the carrying on the slave trade" which authorized private individuals to bring an action for the fine. ${ }^{168}$ The cases the subcommittee cites, read together, merely establish that an informer may initiate a qui tam action when expressly authorized by statute.

A staff memorandum dealing more extensively with the question of qui tam actions was published by the subcommittee in September of $1970 .{ }^{169}$ The authorities reviewed in the attempt to determine whether qui tam actions are authorized by statutes providing for a reward to informers neglect to carry the analysis much beyond the specifics of the particular legislation at issue in each case. The most popular statutory formulation-appropriating a portion of the fine "to him who should prosecute the same to effect" 170 -leaves no question of statutory intent. The overwhelming number of reported qui tam cases have arisen under legislation similarly clear. ${ }^{171}$ Apart from occasional dicta, ${ }^{172}$ only one case has interpreted a statute such as section 16 as authority for a private action for a share of the penalty. ${ }^{173}$ The result has been repudiated elsewhere. ${ }^{174}$

Despite the discouraging state of the precedents, they are largely confined to the specific statutes at issue, with the consequence that the crucial question about qui tam actions under the Refuse Act is likely to be resolved on the face of the legislation. By declaring that "on conviction thereof" the defendant "shall be punished" as prescribed,

166 House Comm. on Gov't Operations, Our Waters and Wetlands: How the Corps of Engrneers Can Help Prevent Their Destruction and Pollution, H.R. REP. No. 917, 91st Cong., 2d Sess. 17 (1970) (footnotes omitted).

167 United States ex rel. Marcus v. Hess, 317 U.S. 537 (1943).

168 Adams, qui tam v. Woods, 6 U.S. (2 Cranch) 336 (1805).

169 QUI TAM Actions, supra note 54.

170 Quoted in In re Barker, 56 Vt. 1, 22 (1884) ; see, e.g., Act of Mar. 22, 1794, ch. 11, $\S 2,1$ Stat. 349; Act of June 8, 1872, ch. 334, $\$ \$ 7,317,17$ Stat. 292, 325.

171 E.g., Williams v. Wells Fargo \& Co. Express, 177 F. 352 (8th Cir. 1910); United States v. Mon Kee Lee, 12 F. Supp. 458 (N.D. Cal. 1935) ; United States v. Laescki, 29 F. 699 (N.D. I11. 1887) ; United States v. Griswold, 24 F. 361 (D. Ore. 1885) ; Pike v. Madbury, 12 N.H. 262 (1841); State ex rel. Mitchell v. City of Shawnee, 167 Okla. 582, 31 P.2d 552 (1934) (dictum).

172 United States ex rel. Marcus v. Hess, 317 U.S. 537, 541 n.4 (1943).

173 Chicago \& A.R.R. v. Howard, 38 Ill. 414 (1865).

174 Omaha \& R.V. Ry. v. Hale, 45 Neb. 418 (1895). 
before spelling out the reward provisions, section 16 appears to make payment conditional upon "giving information which shall lead to conviction." As in the case of other offerors, one who holds out such a reward can limit his offer as he pleases. The explicit reservation allowing a fine "in the discretion of the court," which differs from mandatory provisions found elsewhere, ${ }^{175}$ further undercuts the theory that the informer has a right to something prior to conviction. Unlike the ancient English practice ${ }^{176}$ an action for the reward today would be viewed as a civil suit. ${ }^{177}$ The statutory provision which permits, in the discretion of the court, a reward upon conviction scarcely provides a definitive basis for recovery prior to prosecution. Those district courts which have considered the issue agree that no private action can precede a conviction. ${ }^{178}$

Policy considerations point in the same direction. Section 17 provides, and the reported cases stress, ${ }_{179}^{179}$ that: "The Department of Justice shall conduct the legal proceedings necessary to enforce the provisions of sections [13 and 15] of this title." 180 Moreover, section 17 insists "it shall be the duty of the United States Attorneys to vigorously prosecute all offenders whenever requested to do so by [the

17518 U.S.C. \$962 (1964); 25 U.S.C. \$201 (1964); 26 U.S.C. \$7273(b) (1964). Congressman Reuss argues persuasively that the insertion of a comma following the phrase "in the discretion of the court" indicates that the judge is to have discretion to impose both a fine and imprisonment, but he has no discretion to wipe out one-half of the fine otherwise due to the person giving the information. Letter from Representative Henry S. Reuss to William H. Rodgers, Feb. 1, 1971, on file in Biddle Law Library, Univ. of Pa. Law School. This reading, however, founders on the point that the court can choose between a fine "or" imprisonment "or" both and by choosing imprisonment effectively can deny the informer a share of the fine. Another discretionary factor enters in the decision concerning whether the person has given "information which shall lead to conviction." See note 184 infra. And even if an informer had an uncontestable right to one-half of all fines, criminal conviction appears a condition precedent to the reward.

176 The English experience is discussed in QUI TAM Actions, supra note 54.

177 See 28 U.S.C. $\$ 2461$ (a) (1964). The Reviser's note explains that this subsection "was drafted to clarify a serious ambiguity in existing law." Cited are qui tam statutes and cases, including United States ex rel. Marcus v. Hess, 317 U.S. 537 (1943) (qui tam suit is civil for purposes of double jeopardy) and Hepner v. United States, 213 U.S. 103 (1909) (directed verdict in favor of the government was permissible since the action to recover statutory penalty was civil, not criminal). Qui tam actions under $\$ 13$ are clearly civil suits.

178 Enquist, qui tam, United States v. Quaker Oats Co., No. 71-0-144 (D. Neb. May 6, 1971) ; United States ex rel. Mattson v. Northwest Paper Co., 327 F. Supp. 87 (D. Minn. 1971) ; Reuss v. Moss-American, Inc., 323 F. Supp. 848 (E.D. Wis. 1971); Bass Anglers Sportsman's Society of America v. U.S. Plywood-Champion Papers, Inc., 324 F. Supp. 302 (S.D. Tex. 1971); Bass Angler Sportsman Society v. United States Steel Corp., 324 F. Supp. 412 (N.D. Ala. 1971); Durning v. ITT Rayonier, Inc., No. 9070 (W.D. Wash. Oct. 5, 1970).

179 See Bass Angler Sportsman Society v. United States Steel Corp., 324 F. Supp. 412 (N.D. Ala. 1971); cf. Confiscation Cases, 74 U.S. (7 Wall.) 454 (1868).

18033 U.S.C. $\$ 413$ (1964). 
Corps of Engineers and other named officials]." This is not to say that the Department of Justice has unreviewable discretion to pick and choose among Refuse Act offenders. ${ }^{181}$ But there is some tentative support for the oft-repeated point ${ }^{182}$ that a plethora of qui tam actions could disrupt even the modest governmental enforcement program now underway.

The inexhaustible supply of vulnerable defendants includes some who have committed themselves to extensive capital investments to minimize discharges in accordance with state or federal requirements; yet these could be singled out in a qui tam suit. Difficult problems of preclusion might arise if ineptly or collusively litigated qui tam actions were held to foreclose the government's options in later cases. Worse, a qui tam onslaught could cause the Corps of Engineers to churn out permits for the asking, with little thought given to restrictions by which these permits should be conditioned.

The distuption argument plainly breaks down, however, where neither the prosecutor nor the administrative authority is doing its job. The citizen suit is an essential lubricant to a creaky enforcement apparatus. A monetary incentive, such as counsel fees or a share of the fine, would help assure enforcement. At any rate, the Congress in 1971 is likely to resolve whether the qui tam false alarm in the Refuse Act should be given explicit statutory sanction and definition in amendments to the Federal Water Pollution Control Act. ${ }^{183}$

\section{Requirement of New Information}

Not only does a conviction appear a sine qua non to qui tam recovery under the Refuse Act, but section 16 also limits payment to one who has supplied "information which shall lead to conviction." This feature plainly invites scrutiny of the materiality of the informer's contribution to a successful prosecution. To tell the prosecutor that an oil refinery in his district is discharging effluent into a river is to tell him nothing that he should not already know. Nor should the reward turn on winning a race in drafting a complaint. The requirement of information "which shall lead to conviction" implies that the informer

181 See text accompanying notes 257-60 infra; cf. Wyandotte Transportation Co. v. United States, 389 U.S. 191 (1967); Note, The Refuse Act of 1899: New Tasks for an Old Law, 22 HAsTrNGS L.J. 782, 800-01 (1971) ("An action qui tam is not literally an enforcement action, but is a civil action by the informer to recover a portion of the penalty set out in the statute under which the action is brought.").

182 See text accompanying note 196 infra.

183 For a discussion of the bills now undergoing intensive consideration, see NADER REPORT, supra note 8 , ch. XX, at 30-42a. 
must supply a missing material link in the chain of evidence making a conviction possible. ${ }^{184}$

Obvious cases which would result in recovery would be the production of information on isolated discharges of oils, garbage, junk, and the like. The dearth of data about more sophisticated industrial water pollution suggests that an informer also could uncover information about stationary sources which might lead to a conviction. The nationwide monitoring effort recently undertaken by the Scientists' Institute for Public Information is typical of the private endeavors that might uncover valuable information. ${ }^{185}$ But even under these circumstances recovery is conditioned upon a successful prosecution by the Attorney General, and is thus speculative.

Concluding that section 13 does not authorize an informer to sue for his share of the reward before the Justice Department secures a conviction is not as disappointing to environmentalists as it may sound. The issue is simply not that important. Widespread criminality under section 13 is a temporary embarrassment, which will be eliminated when the Corps of Engineers begins dispensing permits to the applicants now crowding into its regional offices. Anyone interested in more than publicity should attempt instead to influence the conditions which will appear in section 13 permits. Enforcing those obligations once prescribed, of course, will be a continuing concern for both the agencies and the citizenry. But over the long run, enthusiasm about qui tam actions is unlikely to be a guarantor of water quality.

\section{Fixing the Responsibility of the Prosecutor}

The suggestion that thousands of citizens will undertake expensive and time-consuming lawsuits at the prospect of an informant's reward conditioned upon judicial discretion ${ }^{186}$ is highly questionable. It is more likely, as the Vermont Supreme Court observed in 1884, that "[f]ew persons would undertake the burden of prosecution for the chance of the moiety, while many would be willing to give information of violations." 187 The people want some action against water polluters. They expect the Attorney General to initiate this action. Agitation about qui tam actions no doubt would subside were the responsible authorities to act whenever supplied with evidence sufficient to secure a conviction. 1970).

184 See United States v. Transit-Mix Corp., No. 70-Cr-844 (S.D.N.Y. Dec. 11,

185 See Mercury Monitoring Program, 12 Environment, Sept. 1970, at S-4.

18633 U.S.C. $\$ 411$ (1964).

${ }^{187}$ In re Barker, 56 Vt. 14, 23 (1884). 
That the fundamental quarrel is with the exercise of discretion by the prosecutor is manifested by the fact that the Attorney General's policy under the Refuse Act has become an important test of the commitment of the Nixon administration to environmental quality.

The Justice Department, jealously protecting its prerogatives, opposes not only qui tam actions but other private initiatives in pollution cases, asserting possible disruption of regulatory programs. ${ }^{188}$ The Department also reportedly opposed the President's section 13 permit program, presumably because present enforcement options are virtually unlimited since any manufacturing establishment discharging anything into the water is criminally liable. ${ }^{189}$ These attitudes raise serious questions about the Department's enforcement of the Act. Keeping citizens and bureaucrats out assumes that someone is doing the job. If this is not the case, it is time to challenge the myth of prosecutorial invincibility.

\section{B. The Justice Department and the Refuse Act}

\section{The Evolution of Policy}

Beginning in the 1960's, the Refuse Act and related harbor pollution legislation ${ }^{190}$ have served some four hundred times as the basis for criminal charges against water polluters. ${ }^{191}$ Early in 1970 the Attorney General was churning out press releases reporting about polluters being called to task under the "little used" provisions of the Refuse Act. In February Attorney General Mitchell announced the filing of criminal informations against "several companies and one individual in the Chicago area" charging them with depositing "unusual amounts of solid waste materials into the Calumet River and Lake Michigan." 192 One month later he announced the filing under the Refuse Act of the "first" suit against a thermal polluter. ${ }^{193}$ On Law Day, Deputy Attorney General Richard Kleindienst announced that United States Attorneys "throughout the country" had "stepped up enforcement of the old Refuse Act of 1899," initiating some sixty-six prosecutions between October

188 See S. 3575 Hearings, supra note 156, at 123 (Shiro Kashiwa, Ass't Att'y General, Land \& Natural Resources Division, testifying on Justice Department views on the Environmental Protection Act of 1970).

189 Based on confidential conversations with administration officials.

19033 U.S.C. $\$ \$ 441-454$ (1964).

191 Wall St. J., Dec. 10, 1970, at 28, col. 1 (western ed.).

192 Dep't of Justice Press Release (Feb. 9, 1970).

193 Dep't of Justice Press Release (March 13, 1970). 
1, 1969, and April 15, 1970. ${ }^{194}$ Broad claims were made about "future federal involvement on a large scale." Doubtless, in the next few years the Department will proceed against individuals and businesses "that sully the environment whenever criminal prosecution is thought to contribute to desirable objectives of society." ${ }^{195}$

Conceding the necessity of prosecution whenever appropriate "to contribute to desirable objectives of society" is to concede nothing embarrassing. In fact the Justice Department was less than anxious to acknowledge that criminality had become commonplace under the 1899 Act. Increased congressional attention and a flood of requests from informers, however, soon forced a showdown. Illustrative is the experience of the United States Attorney for the Western District of Washington, who in April 1970 received a citizens' demand that he commence prosecution of twenty-seven Washington state pulp mills, generating a combined waste load with a BOD equivalent to that of nine million people. ${ }^{196}$ The pulp mills, like their counterparts in many other parts of the country, had no section 13 permits. Following hurried consultation with state officials and Justice Department superiors, the U.S. Attorney came up with this reading:

It is the concensus [sic] view that pulp mills which have agreed to comply with water quality standards and their implementation as set by the Federal Water Quality Administration and the Washington State Pollution Control Commission are not in violation of Section 407 of Title 33, United States Code, as alleged.

As you know, the Federal Water Pollution Control Act specifically provides that it is the intent of Congress that the state shall have primary responsibility for the control of water pollution within its own area. Prosecuting a pulp mill which has been issued a state permit on the theory that it should have applied for a federal permit would tend to subvert rather than support the state program. ${ }^{197}$

This is a bit like saying that although the law makes criminal dumping refuse without a permit it is not a crime to dump refuse without a

194 Address Before the Chicago Chapter of the Federal Bar Association, Apr. 30,1970 , at 8 .

195 Id. 9.

196 Upon rejection of the request to initiate a prosecution, the complaint in Durning v. ITT Rayonier, Inc., Civ. No. 9670 (W.D. Wash. Oct. 5, 1970), was filed. See note 178 supra.

197 Letter from Stan Pitkin, United States Attorney, Western District of Washington, to Marvin Durning, May 13, 1970, on file in Biddle Law Library, Univ. of Pa. Law School. 
permit. Little progress was made by the administration with the testimony of Mr. J. J. Lankhorst, Assistant General Counsel, Corps of Engineers, who appeared on May 8 before the Senate Subcommittee on Energy, Natural Resources and the Environment. In a curious statement, obviously coming in the midst of a reassessment of section 13 permit policy, Mr. Lankhorst recited the uniformly generous interpretation given the Refuse Act by the courts and expressed his belief that the Act should be "responsibly enforced in proper juxtaposition with other pollution acts." Pending a "memorandum of understanding," 198 the Corps of Engineers districts were being instructed "to refer reports of pollution to the local office of the Federal Water Quality Administration for investigation, comment, and recommendation as to whether action should be taken under the Refuse Act." ${ }^{999}$

Reacting strongly to the Lankhorst statement, Congressman Reuss, Chairman of the Subcommittee on Conservation and Natural Resources, wrote the Attorney General asking, among other things, the basis upon which FWQA had authority to conduct investigations under a statute it does not administer and requesting clarification of the Department's prosecution policy. ${ }^{200}$ The reply of Assistant Attorney General Shiro Kashiwa spelled out the Justice Department's policy. He noted that "prosecutive discretion is always essential," a point manifestly confirmed by frequent violations of law. He explained that the policy of referring reports to FWQA applied only to "continuing industrial discharges, and not to the isolated, noncontinuous deposits of refuse material unrelated to any program within the jurisdiction of the Federal Water Quality Administration." 201 And he condemned as "patently poor prosecutive judgment" the bringing of an action which would have a "disruptive or devitalizing effect" upon programs designed or approved by FWQA. ${ }^{202}$ Admittedly it would be a "patently poor decision" to "disrupt and devitalize" compliance programs. On the other hand, it would show remarkable common sense to breathe new life into a moribund administrative scheme with the stimulus of criminal sanctions.

\section{a. The 1970 Guidelines}

The contours of the Justice Department's prosecutorial policy received a more complete explanation with the distribution to each

198 Subsequently published as part of the proposed Refuse Act Permit Program. 36 Fed. Reg. 983 (Jan. 20, 1971).

199 Mercury Hearings, supra note 2 , at 25.

2001 [Current Developments] BNA ENv. REP. 157 (June 12, 1970).

$201 \mathrm{Id} .158$.

202 Id. 
United States Attorney of Guidelines for Litigation Under the Refuse Act in June of $1970 .^{203}$ Though formally withdrawn early in 1971 as part of the new permit program, ${ }^{204}$ they contained the substance of a prosecutorial policy that may continue despite the decision to issue permits. Thus, an analysis of the prosecutor's role articulated therein would be useful.

The 1970 guidelines set forth an unexceptional summary of the statute followed by a stated policy of distinguishing between accidental discharges and continuing industrial pollution. "To this end," the instructions encouraged United States Attorneys "to use the Refuse Act to punish or prevent significant discharges, which are either accidental or infrequent, but which are not of a continuing nature resulting from the ordinary operations of a manufacturing plant." Concededly, said the instructions, "[d] ischarges of this last type . . . pose the greatest threat to the environment-but it is precisely this type of discharge that the Congress created the Federal Water Quality Administration to decrease or eliminate, and it is to the programs, policies, and procedures of that Agency that we shall defer with respect to the bringing of actions under the Refuse Act." Consequently, without prior authorization from an Assistant Attorney General, United States Attorneys were forbidden to initiate prosecutions in certain categories of cases: (1) "against . . . any person acting pursuant to a license from [a] State, County, municipality or other political subdivision;" (2) "where the defendant is or has been a party to an administrative proceeding which has been or is being conducted by the Federal Water Quality Administration;" (3) "where the defendant's allegedly unlawful activity is the subject of abatement litigation or criminal prosecution initiated by a State, County, municipality or other political subdivision." 205

In other words, the industrial polluter who is operating under the blessing of a state permit, or who is being pursued in a state prosecution, or who has fallen under the watchful eye of a conference proceeding presided over by FWQA was no longer to be fair game for the United States Attorney. The withdrawal of prosecutorial authority was nearly complete. The industrial entrepreneur who has not bothered to pick up a permit from a local official would be something of an oddity. Pollution discharge permits, like drivers' licenses, are usually for the asking. There may be somewhere a cantankerous and marginal food processor who has not yet bothered to fill out an application blank for

2031 [Current Developments] BNA ENv. REP. 288 (July 17, 1970).

201 See 1 [Current Developments] BNA Env. Rep. 1099 (Feb. 12, 1971).

2051 [Current Developments] BNA ENv. REP. 288 (July 17, 1970). 
a permit, but the pulp and steel mills, oil refineries, chemical and aluminum plants, and electrical utilities which are responsible for most of the pollution load customarily are sufficiently respectable to conform to the modest formalities imposed by local water pollution regulators. Under the guidelines the discretion of the local United States Attorney was confined largely to picking and choosing among the garbage dumpers, bottle throwers, leaf disposers, and others who preferred navigable waters to the local landfill. The restrictive scope of the guidelines with regard to the major industrial offenders demands sceptical scrutiny.

\section{b. Critique of the 1970 Guidelines}

\section{(i) Responsibility at the Top}

These directives reducing local United States Attorneys to arbiters over the inconsequential tend to blur the role of discretion within federal criminal law. The 1970 guidelines made mandatory administrative responsibility at high levels. This is inevitable if not always desirable. Initiating prosecutions against local favorites who happen to be major contributors to the party in power no doubt would jeopardize a United States Attorney's tenure unless the national administration is firmly committed to uniformly enforcing pollution control laws. A prosecutor whose ideas of appropriate defendants do not coincide with those of the administration may have to look for another job. ${ }^{206}$

This may be unwise when the real issues of pollution arise at the local level where the impact on the environment is felt most directly. Although the prosecutor may be subjected to local pressures just as the Attorney General is subjected to national influence, he is a federal official and as such might be able to make his decisions in a more dispassionate atmosphere were he left unsupervised by his superiors. Thus, though probably true, it is unfortunate that a United States Attorney must refrain from filing charges against, let us say, either United States Steel, which is operating under an implementation plan approved by FWQA, or General Motors if its executives persuade the Attorney General that this initiative would be imprudent. Whether motivated by the deepest concern for the environment or the basest of political motives, the Attorney General does and should exercise final responsibility for the administration of the Refuse Act. Those who disagree

206 For a discussion of the reported firing in New York of an Assistant United States Attorney who held out for criminal action instead of a civil suit against General Motors, see Wall St. J., Jan. 11, 1971, at 15, col. 3 (western ed.). The suit was ultimately settled by consent decree. 
with a decision, especially one based on political considerations, can object in the next presidential election. ${ }^{207}$

Nonetheless, the message from the Justice Department, confirmed by other evidence, sounded very much like a declaration of an intention to consign the 1899 Act to rare use as an implement in the water pollution arsenal. One could fairly conclude that the guidelines spelled out a policy of restraint to be followed at all levels of the Justice Department. The point deserves discussion.

\section{(ii) Inescapable Discretion}

The prosecutor must have discretion to enforce the criminal law. Developing guidelines to confine that discretion and defining the scope of judicial review have received considerable attention in recent writings. $^{208}$ To date, academic concern has been devoted largely to articulating restrictions on a prosecutor's power to track down hapless individuals who run awry of the countless junk proscriptions in our criminal codes. ${ }^{209}$ Devising a structure to protect the unwary corporate polluter and his victim but adds a new dimension to an old problem.

Some sympathy for the problems of the prosecutor in developing a principled discretion is in order. Default by the Corps of Engineers under the Refuse Act leaves the prosecutor responsibilities to pick and choose among thousands of offenders who discharge refuse without permits. His problems of proof are relieved but not obviated by the per se proscriptions of the Act. Having insufficient investigative authority of his own, ${ }^{210}$ he must look to state agencies, the Corps, the Coast Guard, or FWQA to supply evidence for prosecution. It also may be conceded that a prosecutor might prefer evidence supplied by a federal agency to, let us say, proof uncovered by the investigation of unproven nongovernmental groups. The Attorney General, by

207 The revised guidelines provide only that:

Prior to the filing of civil complaints, criminal informations and the return of indictments in Refuse Act cases, the United States Attorney shall telephonically contact the Land and Natural Resources Division.

1 [Current Developments] BNA ENv. REP. 1099 (Feb. 12, 1971). Even if this means that advice from above may be offered on whether the suit should be filed, the Justice Department deserves credit for loosening what appeared to be political reins on the United States Attorneys under the 1970 guidelines.

208 See, e.g., K. Davis, Discretionary Justice (1969).

209 See, e.g., Rodgers, Desuetude as a Defense, 52 Iowa L. Rev. 1 (1966).

210 For example, in the entire Western District of Washington, a coastal region containing hundreds of point sources, a fraction of the time of one man is devoted to prosecutions for violations of anti-pollution laws. 
reason of restraint, habit, and resources, has very little original initiative over administrative criminal offenses. This is illustrated too often and too indelibly by instances of wholesale criminality tolerated by agencies which, having day-to-day regulatory responsibilities over the offenders, refrain from requesting prosecution. ${ }^{211}$ Consequently, the prosecutor, with sweeping and virtually unreviewable discretion to decide whether to press charges, defers to a line administrator who exercises a similarly sweeping and virtually unreviewable authority to excuse violations. Rarely will a violator fail to escape at one level or the other.

In theory, an agency's restraint should not determine prosecutorial policy. The law is replete with instances where one authority may condition action upon an evaluation whether the job is being done by the institution principally responsible. Attorney General Robert Jackson, during his tenure, flatly refused to prosecute criminal libel cases "where there is open to the individual a civil remedy, and where there has been no breach of the peace or other public injury done by the libel." 212 The availability of a suitable civil remedy, coupled with a respect for freedom of speech and a fear of being inundated with claims, were thought sufficient reasons for restraint. Criteria suggested for allowing federal prosecutions under criminal laws that are merely auxiliary to state law enforcement may include " $[\mathrm{w}]$ hen the states are unable or unwilling to act" or "when it would be inefficient administration to refer to state authorities a complicated case investigated and developed on the theory of federal prosecution." 213 A federal prosecutor also might justifiably stay his hand against conduct regulated by state law unless faced with a precedent-setting fact situation or an especially culpable offender. ${ }^{214}$

Other illustrations of principles which might be invoked in determining the scope of prosecutorial discretion under the Refuse Act read like a litany of administrative law. Procrastination, ${ }^{215}$ a history of

211 See, e.g., House Comar. on Gov't Operatrons, Deficiencies in AdministraTION OF FEDERAL INSECTICIDE, FungICDE AND RODENTICIDE ACT, H.R. REP. No. 637, 91st Cong., 1st Sess. 26-27 (1969).

212 Hearings on Nomination of Robert H. Jackson to Be an Associate Justice of the Supreme Court Before the Subcomm. on the Jackson Nomination of the Senate Comm. on the Judiciary, 77th Cong., 1st Sess. 55 (1941) (letter from Attorney General Jackson to Senator Millard Tydings).

213 Schwartz, Federal Criminal Jurisdiction and Prosecutors' Discretion, 13 LAW \& Contemp. Prob. 64, 73 (1948).

214 See M. Paulson \& S. Kadish, Cases and Matertals on Cruminal Law aNd Its Processes 1069-70 (2d ed. 1969).

215 Cf. Smith v. Illinois Bell Tel. Co., 270 U.S. 587, 591 (1926) ; Environmental Defense Fund, Inc. v. Hardin, 428 F.2d 1093, 1099 (D.C. Cir. 1970). 
discrimination, ${ }^{216}$ a demonstrated disinterest, ${ }^{217}$ or the lawless abuse of administrative power ${ }^{218}$ _activity which would justify judicial intervention in agency actions-are bases upon which such discretion could be grounded. The familiar exhaustion of administrative remedies argument is unpersuasive against Refuse Act prosecutions if evidence indicates that agency efforts are likely to be futile. ${ }^{219}$ The considerations supporting injunctive relief against purposeful discrimination in the enforcement of a criminal statute ${ }^{220}$ suggest that it would be similarly appropriate for a prosecutor to invoke Refuse Act sanctions in situations in which a state discriminatorily excuses certain water polluters from their legal obligations. The obvious point is that inaction by one responsible administrative authority is no reason for other agencies with a comparable authority to acquiesce. ${ }^{21}$ The prosecutor must make his own judgment about the circumstances in which administrative inaction calls for his intervention. The decision should be influenced but not controlled by deliberations of EPA or the Corps of Engineers. The extent to which the 1970 guidelines are consistent with this conclusion and the possibility of an administrative attitude coloring enforcement under the recently revised Justice Department guidelines ${ }^{222}$ remain to be explored. A critique of the nature and potential use of the 1970 guidelines should further this discussion.

\section{c. Guideline Reasons for Failure to Prosecute}

(i) "persons operating pursuant to a license from a State, County, municipality or other political subdivision."

Counseling restraint against criminal punishment of conduct licensed and approved by local authorities is a commendable concession to the delicate balance between state and federal government. The working assumption should be that local officials would not presume to approve activity offensive both to the interests of its own population

216 See Jeffers v. Whitley, 309 F.2d 621, 628 (4th Cir. 1962).

217 See Note, Judicial Acceleration of the Administrative Process: The Right to Relief from Unduly Protracted Proceedings, 72 YALE L.J. 574, 585-86 (1963).

218 See Leedom v. Kyne, 358 U.S. 184 (1958).

219 See Walker v. City of Birmingham, 388 U.S. 307, 318-19 (1967) (dictum).

220 See Dombrowski v. Pfister, 380 U.S. 479 (1965).

221 For example, in 1969 a federal judge refused to find preemption in a suit by New Jersey against several major airlines where the defense was based on a showing that the Administrator of the Federal Aviation Administration would propose regulations to control emissions from jet aircraft. See J. Esposito, VANISHING AIR 148-49 (1970) (The Ralph Nader Study Group Report on Air Pollution).

222 See note 204 supra. 
and the federal water quality program. But here, put bluntly, the issue is under what circumstances should a state tolerance policy, expressed in the form of a permit, be found sufficiently objectionable to inspire the prosecutor to invoke the Refuse Act.

That state permits may be nothing more than a documented sellout or a form utterly irrelevant to the problems of pollution is unarguable. Under most state laws an industrial polluter is obliged to secure a permit authorizing discharges, often conditioned upon disclosures about the nature of the manufacturing process and the effluent produced. ${ }^{223}$ Disclosure may be incomplete, haphazard, and misleading. A recent examination by the Comptroller General of the state permit files on eighty industrial plants discharging wastes into one river showed that many did not contain information on BOD, volume of wastes, or suspended solids :

[I]nformation on BOD was contained in the permit files for only 30 plants and information on the volume of wastes was contained in the files for 52 plants. However, for 22 of the 52 plants, the files did not contain sufficient information for us to ascertain the nature and volume of the wastes which were permitted to be discharged into the river. ${ }^{224}$

For more exotic kinds of discharges, state officials may be told nothing. Illustrative is the recent disclosure that questionnaire surveys of chemical industry wastes in California revealed a solid-wastegeneration factor of almost twice that earlier thought to exist. ${ }^{225}$ Neither of the industrial sources of mercury in the State of Washington, Georgia Pacific Corp. and the Weyerhauser Co., mentioned the chemical as a possible contaminant in their permit applications, ${ }^{226}$ an omission that is technically a misdemeanor under state law. ${ }^{227}$ Numerous compounds to be discharged in the effluent, ${ }^{228}$ including zinc, were recently ignored in a state permit granted to the Atlantic-Richfield Co., which is opening a refinery to process the expected oil flow from the Alaska

223 See, e.g., Wash. REv. Code ANN. $\$ \$ 90.48 .160,90.48 .170$ (Supp. 1970).

224 Comptroller General's Report to the Congress, Examination Into the Effectiveness of the Construction Grant Program for Abating, Controling and Preventing Water Poliution 60 (1969).

225 Selected Problems of Hazardons Waste Management in California 13-17, in State of California Report of the Governor's TASK Force on SOLID WASTE Management (1970), reprinted in Resource Hearings, supra note 130, pt. 5, at 2606.

226 Based on personal examination of files in the Washington State Department of Ecology.

227 Waser. Rev. Code Ann. $\$ 90.48 .140$ (1962); id. $\$ 90.48 .170$ (Supp. 1970).

228 Based on personal examination of files in the Seattle Office, Army Corps of Engineers. 
slope. It is enough to suggest that a polluter's ability to mystify, bluff, or out-bargain, a state or local official in a permit proceeding is a poor measure of the Attorney General's responsibility under the Refuse Act. That the Justice Department need not always be deterred by the punctilios of state permits was demonstrated quite decisively during the mercury crisis. ${ }^{220}$

Definitive guidelines are difficult to develop. At a minimum, pointing to a piece of paper should be the beginning, not the end, of federal review of state or local institutional commitment to the solution. The prosecutor should inquire further about the vigor with which disclosure obligations and compliance schedules are being pursued under the permit, the wisdom of the treatment objectives there set forth, and the integrity and strength of the administrative commitment. Not to be overlooked, either, is the salutary effect on negotiations likely to be wrought by ominous rumblings or innocent inquiries from the prosecutor's office. The Justice Department can assist immeasurably in what invariably is an arduous political and economic struggle over technology by maintaining an active interest in Refuse Act prosecutions. Foregoing a prosecution in deference to a state or local permit is desirable only if there exists an acceptable institutional alternative tending to bring about the federal water quality objectives manifested in the Refuse Act.

(ii) "where the defendant is or has been a party to an administrative proceeding which has been or is being conducted by the Federal Water Quality Administration."

This broad concession to the FWQA was unnecessarily generous. Federal water pollution procedures are hobbled at the outset due to the limited powers of the Secretary (now the Administrator of EPA) to call $^{230}$ and then conduct a non-adversary enforcement conference. ${ }^{231}$ In the event of continuing non-compliance, a formal adversary hearing before a hearing board is required, ${ }^{232}$ followed finally by court action to secure abatement if the pollution is endangering persons in another

229 The U.S. Dep't of the Interior at one time informed firms accused of mercury pollution that they had three months to reduce effluents to less than half a pound per day, and six months to desist entirely. 12 ENVIRONMENT, Oct. 1970, at S-1 (citing the Washington Post). Clearly, the judicially enforceable criminal or injunctive sanctions of the Refuse Act are but one factor among many in a continuous bargaining process between the regulators and the regulated.

23033 U.S.C.A. $\$ 1160$ (d) (1970). An excellent history appears in Barry, The Evolution of the Enforcenent Provisions of the Federal Water Pollution Control Act: $A$ Study of the Difficulty in Developing Effective Legislation, 68 MrcH. L. REv. 1103 (1970).

23133 U.S.C.A. $\$ 1160$ (d) (1970).

232 Id. $\$ 1160(\mathfrak{f})$. 
state. ${ }^{233}$ But formal hearings are almost unheard of. ${ }^{234}$ One participant notes the adoption of informal procedures designed to function effectively without lawyers and their intimidating, argumentative ways. ${ }^{235}$ Compromise, discussions, and bargaining are the names of the conference game.

Mr. Murray Stein, the FWQA official who has presided over most of the conference proceedings to date, has affirmed that:

Experience with our specific water pollution problems has shown that an equitable solution can almost always be achieved if all parties approach the problem with goodwill, reasonableness, and respect for our democratic governmental process. ${ }^{236}$

But where this is not the case, "equitable solutions" are unlikely. As an example, an agency report of what has happened to the recommendations arising out of the conference on pulp mill pollution of Puget Sound, held in Washington State during 1962 and 1967, concedes that "[i]n some cases compliance is not satisfactory." ${ }^{237}$ Asked why he did not have ITT-Rayonier Corporation and Scott Paper Company brought into court to enforce compliance, $\mathrm{Mr}$. Stein pointed out that if the effects of the pollution are not felt in another state he had no such authority under the law unless he received "written consent" from the Governor. ${ }^{238}$ And state officials have alleged: "There should be a solid front formed in these negotiations by the state and federal governments. But sometimes there's a crack in the wall . . . ." 239

In case after case, conference recommendations are reduced to a series of precatory reminders. In the jargon of bureaucracy, "slippage" is the euphemism used to describe a failure to meet the obligations decreed by a water pollution conference. ${ }^{240}$ The reasons for

233 Id. $\$ 1160$ (g).

234 Before 1970 there had been but four public hearings and one court action. Stein, The Actnal Operation of the Federal Water Pollution Control Administration, 3 Nar. Res. Law. 41, 45-6 (1970). 1 [Current Developments] BNA ENv. Rep. 100 (1970) reports one hearing since then.

235 Quigley, "Laws, Lazyyers and Pollution," 3 Nar. Res. Law. 112, 113 (1970). 236 Stein, supra note 234, at 46.

237 Enforcement Actions Under the Federal Water Pollution Control Act, 1 [Fed. Laws] BNA ENv. Rep. 41:5201, 41:5203 (1970) [hereinafter cited as Enforcement Actions].

238 See Wilson, Puget Sonnd Pollution: A Case History, Seattle Times, Feb. 16, 1970 , at 1 , col. 8 .

239 Seattle Times, Feb. 17, 1970, at 11, cols. 7-8 (quoting James Behlke, Director, Washington State Water Pollution Control Commission). The disputes with both ITT-Rayonier and Scott Paper were subsequently settled.

240 See, e.g., Federal Water Pollution Control Administration, Progress Evaluation Meetung in the Matmer of Pollution of Lake ERIE \& Its Tributaries 531 (1969) [hereinafter cited as Evaluation MeEting]. 
"slippage" are many and varied. In Washington State, deadlines set by the federal conference on pulp mill pollution in Puget Sound have been unilaterally extended by state officials less than anxious to offend major local employers. ${ }^{241}$ Conflicts of interest on state boards are notorious. ${ }^{242}$ The recently published Nader Report on water pollution supplies extended documentation of what is now the expected pattern of administrative cowardice, favoritism, and foot-dragging. ${ }^{243}$

The interminable duration of the water pollution conference is worthy of special comment. In 1969 Congressman Charles Vanek reported:

The Hammermill Paper Company was ordered to begin treatment of its wastes more than twenty years ago on February 26,1946 , but has been granted ten extensions. As of June last year "negotiations" were continuing but an "agreement" had not yet been reached. ${ }^{244}$

A look at FWQA's description of its own proceedings offers further evidence of the endless nature of the conferences. The Potomac River conference, which first convened on August 22, 1957, ${ }^{245}$ has already celebrated its thirteenth birthday. The conferees agreed in October of 1970 to expand the major waste treatment facility, with a completion date of 1977, even though they recognized that "population projections for the suburban areas will outpace the capacity of the . . . plant by $1977^{\prime 246}$ and agreed to the need for additional facilities. A week later Secretary Hickel expressed dissatisfaction with this plan by setting a 1974 deadline and calling for quarterly rather than semi-annual meetings for review of progress, presumably in an effort to keep "slippage" to a minimum. ${ }^{247}$ Pollution of the Potomac River continues as a national disgrace. ${ }^{248}$

The Kansas City Metropolitan Area Conference also first convened 13 years ago. FWQA reported in 1970 that "industries are taking

241 Compare Federal. Water Pollution Control Admintstration, Confrerence on the Matter of Polnution of the Navigable Waters of Puget Sound, THe

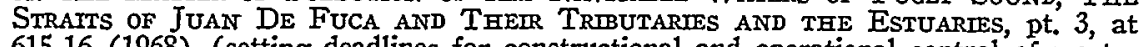
615-16 (1968) (setting deadlines for constructional and operational control of wastes by Rayonier Incorporated from its Port Angeles pulp mill) with Washington Water Pollution Control Commission, Permit No. T-2867 (March 30, 1970) (extending deadline by nearly two years).

242 N.Y. Times, Dec. 7, 1970, at 1, col. 1.

243 NADER REPORT, supra note 8, ch. X, passim.

244 Evaluation Mieming, supra note 240 , at 537.

245 Enforcement Actions, supra note 237, at $41: 5201$.

2461 [Current Developments] BNA ENv. REP. 641 (1970).

247 Id. 652.

248 See N.Y. Times, July 12,1970 , at 46 , cols. $1-8$. 
action to comply." 249 The Tennessee-Virginia Conference, commenced in 1960, produced advice by a technical committee which resulted in a subsequent installation of devices by a chemical company "which partially regulate discharges." ${ }^{250}$ Perhaps this "partial" regulation will contribute in some small way to the "partial" restoration of the polluted Holston River. Given the inexorable administrative process in the water pollution field, it seems quite possible that the longevity records set by the Elizabethan Court of Chancery are in danger of being eclipsed. ${ }^{251}$

Obviously, some offenders are using the administrative process to postpone for extended periods the substantial economic commitments necessary for pollution control. It is this process that the Justice Department avowedly determined to protect from "disruption and confusion" under the 1970 guidelines. Clearly, the Attorney General should not unqualifiedly relinquish his authority to an administrative proceeding that may condone massive "slippage" incompatible with the public interest.

The Attorney General has shown no reticence where a federal agency calls for help under the 1899 Act. It was Secretary Hickel, still presiding over FWQA, who made the announcement about the mercury lawsuits. But a specific request should be unnecessary. The legislation establishing the conference procedures preserves other remedies, including explicitly the Refuse Act. ${ }^{252}$ It may be that the prohibitions of the 1899 Act are in conflict with the policies of conference, compromise, research, and cooperation decreed by the Water Pollution Control Act. But the fundamental objectives of clean water and a healthy environment are the aim of both statutes. The prosecutor should move where the administrative process is demonstrably inoperative or incompetent. And demonstrating readiness and willingness to act also might help erode administrative reluctance to consider the criminal sanction as a realistic enforcement option.

(iii) "where the defendant's allegedly unlawful activity is the subject of abatement litigation or a criminal prosecution initiated by a State, County, municipality or other political subdivision."

Once again, this ground for restraint was well founded as far as it went. Pending litigation at the local level is obviously a strong

249 Enforcement Actions, supra note 237, at $41: 5202$.

250 Id. $41: 5203$.

251 See W. Jones, The Elizabethan Court of Chancery 306-07 (1967).

25233 U.S.C.A. §1174 (1970). 
indicium-perhaps more so than a permit-that action is being taken. Yet "press release" litigation is not unknown in the environmental field. And the tactical, and legal, impact of even the filing of a complaint may be virtually indistinguishable from a hostile press release. Obviously, the Justice Department should not be taken in by such a lawsuit any more than it should be by an uncritically granted permit. The simultaneous prosecution of related actions is not without precedent in our federal system. ${ }^{253}$

\section{Controlling the Prosecutor's Discretion:}

\section{A Search for the Appropriate Remedy}

What has been attempted thus far is a highlighting of deficiencies in the Justice Department's 1970 guidelines under the Refuse Act. To suggest additional structuring of prosecutorial discretion, however, is no answer to the contention that the job of sorting out one polluter from the next is his and his alone. I have argued that the pressing need for information and enforcement justifies the liberalization of remedies to enlist the support of private attorneys general in the water pollution wars. ${ }^{254}$ That Congress neglected to make a qui tam action a part of this arsenal is not so much a repudiation of the need as it is a drafting oversight. Authorizing citizen actions to enforce water quality standards, including section 13 permit conditions, is a central issue before the Congress in 1971.255 With the possibilities of qui tam actions becoming academic under the accumulating precedents, ${ }^{256}$ the need for a reformulated private remedy is compelling.

Doing the job for the prosecutor who doesn't is not the only alternative, however. Another, which is being pursued by Congressman Reuss and others, is to make the scope of prosecutorial restraint under the Refuse Act a political issue. Also there is the possibility of judicial review of a decision not to prosecute. Section 17 proclaims "it shall be the duty of United States attorneys to vigorously prosecute all offenders against [the Act] whenever requested to do so by the Secretary of the Army or by any of the officials hereinafter designated ...." 257 It is at least arguable that that duty extends also to acting upon well founded information supplied by a private party. Federal procedure provides a mechanism to force the hand of a reluctant

253 See, e.g., United States v. Kordel, 397 U.S. 1, 11 (1970).

254 See text accompanying notes 8-18 supra.

255 See note 183 supra.

256 See note 178 supra.

25733 U.S.C. $\$ 413$ (1964). 
prosecutor via mandamus "to perform a duty owed to the plaintiff." 258 Without exploring the nuances of this remedy, however, it would be naive to assume that the use of some mandatory language will overcome the discretion of the prosecutor who exercises unreviewable powers second to none in our system of government. ${ }^{259}$ Despite the bleakness of the precedents, Professor Davis has presented forcefully a case for review of prosecutorial discretion, ${ }^{260}$ which is at least arguably viable under the Refuse Act. Nonetheless, criticizing the Attorney General, however popular the practice, is no substitute for identifying just who holds the key to the effective use of the 1899 statute to control pollution.

\section{The Army Corps of Engineers}

\section{Mired in Tradition}

No institution is in a better position to negate the prosecutor's affirmative exercise of discretion under the Refuse Act than the Army Corps of Engineers. Its authority to issue section 13 permits is the authority to condone that which the Act otherwise condemns. Demonstrably, the wholesale neglect of section 13 means that the law is being violated only so long as permits are not issued. In the next few years, major issues of water quality control affecting thousands of industrial polluters will be settled in the Corps' permit proceedings. Whether effective control of water pollution will emerge from these forums remains to be seen.

A brief look at the Corps' past performance points up the institutional neglect accorded the Refuse Act. To begin the story in modern times, in 1963 the Corps' Chief of Engineers told the Subcommittee on Natural Resources and Power of the House Committee on Government Operations that because a "primary purpose" of section 13 and related statutes "is to protect navigation from obstruction and injury, enforcement has been concentrated on prevention of pollution, including oil, that will impede or injure navigation." 281 A memorandum of law summarizing cases brought under the Refuse Act, submitted to the Subcommittee, cited successful prosecutions for discharges which did not impede navigation. ${ }^{262}$ In September 1963 a Division Engineer reaffirmed that section 13's "primary purpose" was the protection of

25828 U.S.C. $\$ 1361$ (1964).

$259 \mathrm{~K}$. Davis, Discretionary Justice 188 (1969).

$260 I d .211-14$.

2611963 Hearings, supra note 17, pt. 1B, at 1229.

262 Id. 1235. 
navigation, but acknowledged that "[p] ollution matters come within the purview of this act." 263

The Corps' obsession with obstructions to navigation was not to be so easily abandoned. In 1966, during a Congressional inquiry into pollution of the Great Lakes, Representative John Dingell asked a Corps spokesman whether in light of the Standard Oil ${ }^{264}$ decision "there [is] any action the corps can take to deal with noxious deposits of pollutants, oils, tars, industrial wastes, raw sewage into the waterways of the Great Lakes and the Great Lakes Basin?" Came the response: "The law speaks of 'Oil and other refuse which would be a hazard to navigation.' That is my area of concern. Pollution is not included in that." 265 Submitted in support of this view was a brief memorandum of law characteristically deferential to the obstruction requirement. In justification the memorandum quoted a Corps regulation declaring in part:

it has been the long standing policy to secure compliance with its provisions short of legal proceedings. . . . It is the policy not to recommend prosecution when the violation of law is trivial, apparently unpremeditated, and results in no material public injury. ${ }^{26}$

Pollution, it would thus appear, was trivial. The memorandum continued:

[Supreme Court decisions] have not specifically broadened the authority of the Corps of Engineers beyond its historical interest in navigation, except that the Standard Oil case has emphasized that oil pollution resulting from accident is nevertheless punishable under Sec. $13 . . .{ }^{267}$

At other times that year before the Congress, the Corps avoided specifics. Witnesses retreated into vague and obscure language:

The role of the Corps of Engineers in this field is to cooperate and coordinate to the fullest degree, and to engineer to the maximum practicable extent, effective measures which are within the realm of practicable feasibility in those projects for which the Corps has primary responsibility. ${ }^{268}$

263 Id., pt. 3, at 2276.

264384 U.S. 224 (1966).

265 Hearings on Water Pollution-Great Lakes Before the Natural Resources \& Pozver Sibcomm. of the House Comm. on Gov't Operations, 89th Cong., 2d Sess., pt. 3 , at 593 (1966).

200 Id. 595-96.

267 Id. 596.

263 Id. 117-18 (statement of Brigadier General Roy T. Dodge); cf. id. 583 (other statements by Gen. Dodge). 
By 1967, the Corps had returned to normalcy. In the revision that year of its administrative procedures, this legal formula was offered:

The jurisdiction of the Department of the Army, derived from the Federal laws enacted for the protection and preservation of the navigable waters of the United States, is limited and directed to such control as may be necessary to protect the public right of navigation. Action under section 13 has therefore been directed by the Department principally against the discharge of those materials that are obstructive or injurious to navigation. ${ }^{269}$

More recent formulations similarly insisted that section 13 "is administered . . . in the interest of navigation rather than of conservation, public health or sanitation." 270

\section{The Legislative Assault}

In recent years, substantial inroads have been made upon the Corps' confirmed disinterest in pollution. The 1958 amendments to the Fish and Wildlife Coordination Act direct the Corps in connection with dredge and fill permits under section 10 of the Refuse Act to "consult" with the Fish and Wildlife Service and the heads of interested state agencies "with a view to the conservation of wildlife resources" within the impacted areas. ${ }^{271}$ In section 10 cases, the Corps now is obligated to include in the record federal and state reports which indicate "possible damage to wildlife resources" and "measures that should be adopted to prevent the loss of or damage to such wildlife resources . . . "272 To implement this Act and others, the Secretaries of the Army and Interior in 1967 entered into a memorandum of understanding reciting the responsibilities of the Corps under sections 10 and $13^{273}$ and delineating procedures to be followed. The Secretary of the Army, upon a recommendation of the Secretary of the Interior that the "proposed operations will unreasonably impair natural resources or the related environment," will either "deny the permit or include such conditions in the permit as [the Secretary of the Army] determines to be in the public interest, including provisions that will assure compliance with water quality standards established in accordance with the law." ${ }^{274}$ The responsibility for assuring compliance

26932 Fed. Reg. 17,540 (1967).

270 Corps of Engineers, Eng. Reg. 1145-2-301 (July 1, 1968).

27116 U.S.C. $\$ 662$ (a) (1964).

272 Id. $\$ 662(\mathrm{~b})$.

27333 C.F.R. $\$ 209.120$ (d) (11) (1971).

274 Id. 
with water quality standards thus was conceded to be an obligation of the Corps.

The Corps' formal response to the Fish and Wildlife Coordination Act was an acknowledgement pertaining to section 10 permits in its public notice form expressing an interest in receiving views "concerning the effect of the proposed work upon navigation and other matters affecting the public interest." 275 A subsequent revision stated:

The determination as to whether a [section 10] permit will be issued will be based on an evaluation of all relevant factors including the effect of the proposed work on navigation, fish and wildlife, conservation, pollution, and the general public interest. Comments on these factors will be accepted and made part of the record and will be considered in determining whether it would be in the best interest to grant a permit. 276

In 1968 the Corps revised its general permit policy announcing that in considering an application for a permit to conduct activities affecting navigable water the agency would evaluate "all relevant factors, including the effect of the proposed work on navigation, fish and wildlife, conservation, pollution, aesthetics, ecology, and the general public interest." 277

Saying it and doing it, however, are two different things. Over the objection of the Department of the Interior, ${ }^{278}$ the Corps has authorized dredge and fill projects-one of which was deemed a "debacle" by a House Subcommittee. ${ }^{279}$ In that situation, as elsewhere, the Corps demonstrated its continuing pre-occupation with protection of navigation at the expense of environmental values. ${ }^{280}$

Another legislative attack upon the Corps' traditions, the National Environmental Policy Act of 1969 (NEPA), ${ }^{281}$ obligates federal agencies to detail the environmental impact of "major Federal actions significantly affecting the quality of the human environment." ${ }^{282}$ The impact study must describe any unavoidable environmental effects of the proposal, possible alternatives to the proposed action, and any ir-

275 Hunting CREEK REPORT, supra note 106, at 41.

27633 C.F.R. $\$ 209.120$ (f) (5) (1971).

277 Id. $\$ 209.120$ (d) (1).

278 See EstuarIne Study, supra note 9, at 364.

279 Hunting CREEK RePoRT, supra note 106.

280 Id. 40-42.

28142 U.S.C. $\$ \$ 4321-47$ (Supp. V, 1970).

282 Id. $\$ 4332$ (c). 
reversible commitment of resources the proposal would necessitate. ${ }^{283}$ Consultation is required with agencies having special expertise or jurisdiction "with respect to any environmental impact involved." 284 NEPA has been construed to afford the Corps a powerful new weapon to refuse section 10 permits on environmental grounds. ${ }^{285}$

The Water Quality Improvement Act of $1970^{286}$ also affects the Corps. Section $103^{287}$ amended the Federal Water Pollution Control Act to read:

Any applicant for a Federal license or permit to conduct any activity including, but not limited to, the construction or operation of facilities, which may result in any discharge into the navigable waters of the United States, shall provide the licensing or permitting agency a certification from the State in which the discharge originates . . . that there is reasonable assurance . . . that such activity will be conducted in a manner which will not violate applicable water quality standards. ${ }^{288}$

Existing sources are given three years to secure state certification. ${ }^{289}$ Thus, each state agency now has a veto over the issuance of permits by the Corps.

The power to certify assumes a fortiori the power to prescribe conditions, including continuous monitoring, process and design changes, and treatment commitments, which may be routinely incorporated into the Corps' permits. Interestingly, under state administrative law the certification may be deemed a "license," which would have the effect of importing the procedures associated with contested cases-discovery and cross-examination-into the procedures of the public hearing. ${ }^{290}$ Thus, many major water polluters in the country may face both a section 13 permit proceeding before the Corps and a contested hearing before the responsible state agency. ${ }^{291}$ The surreptitious negotiations

\section{$283 \mathrm{Id}$.}

$284 I d$.

285 Zabel v. Tabb, 430 F.2d 199 (5th Cir. 1970), cert. denied, 401 U.S. 910 (1971). 286 Act of April 3, 1970, Pub. L. No. 91-224, 84 Stat. 91.

28733 U.S.C.A. $\$ 1171$ (1970).

$288 I d . \S 1171$ (b) (1).

289 Id. $\$ 1171$ (b) (7).

290 See, e.g., WASH. Rev. Code ANn. $\$ 34.04 .090$ (Supp. 1970).

291 Under 36 Fed. Reg. 6569 (1971) (to be codified at 33 C.F.R. $\$ 209.131$ (k) (1)) repetitious hearings are to be avoided:

[A] public hearing [before the Corps] will not generally be held if there has been a prior hearing (local, State or Federal) addressing the proposed discharge unless it clearly appears likely that the holding of a new hearing may 
which have characterized waste discharge permit proceedings are clearly in jeopardy.

\section{The Administrative Response}

Presently underway is a reevaluation of the policies of the Corps of Engineers as important as any in its history. In May 1970 the Corps-responding to the recommendations of the Reuss Subcommittee ${ }^{292}$-announced "sweeping changes in its regulations pertaining to permits for work in navigable waterways." 293 Soon-to-be superseded declarations were made with respect to disclosures of the character of the effluent, rights of public hearings, and consultations with state and federal officials. In August the Corps announced that "new permits" under section 13 would be required "where existing permits were granted without adequate consideration of the quality of the effluent," which could mean all cases. "While permits will be required for all future discharges into navigable waters and their tributaries," the Corps of Engineers "will initially concentrate on major sources of industrial pollution not covered by existing permits." 284 For a short time, the Corps operated under additional interim procedures for section 13 permits. ${ }^{295}$ With major revisions, the regulations were adopted effective on the date of publication, April 7, 1971.298

result in the presentation of significant new information concerning the impact of the proposed discharge or deposit.

Under the amended Federal Water Pollution Control Act, 33 U.S.C.A. $\$ \S 1171$ (b) (2), (4) (1970), hearings may be mandatory, a point recognized in 36 Fed. Reg. 6569 (1971) (to be codified at 33 C.F.R. $\$ 209.131(\mathrm{k})(5)$ ). Equating all hearings before all forums "addressing the proposed discharge" plainly begs the crucial question of whether any hearing will be adversary. The Corps anticipates no such searching inquiry. See id. (to be codified at 33 C.F.R. $\$ \$ 209.131(\mathrm{k})(3)$, (4)). And, given the potpourri of authorities responsible for control of industrial discharges, it is doubtful that anyone will conduct the adversary hearing needed. See Sive, Some Thoughts of an Environmental Lawyer in the Wilderness of Administrative Law, 70 Colum. L. REv. 612 (1970).

292 See House Comar. on Gov't Operations, Our Wastes and Wetrands: How the Corps of Engmeers Can Help Prevent Their Destruction and Pollution, H.R. REp. No. 917, 91st Cong., 2d Sess. (1970). 1970).

293 U.S. Army Corps of Engineers News Release, Seattle District, at 1 (May 19,

284 U.S. Army Corps of Engineers News Release, Seattle District (Aug. 4, 1970).

295 Telegrams to the District offices in August and September of 1970 contained nothing surprising other than a secrecy provision ("No public announcement is to be made of the procedures set forth above.") incompatible with provisions of the Freedom of Information Act, 5 U.S.C. \$552(a) (1) (B) (Supp. V, 1970) (copies of telegrams on file in Biddle Law Library, Univ of $\mathrm{Pa}$. Law School). This seems a curious way of dealing with issues of public policy as important as the national water pollution control effort.

Later, however, proposed regulations governing the issuance of $\$ 13$ permits were published for public comment. 35 Fed. Reg. 20005 (1970) (proposed 33 C.F.R. $\$ 209.131$ ).

29636 Fed. Reg. 6564 (1971) (to be codified at 33 C.F.R. $\$ 209.131$ ). 


\section{Critique of Refuse Act Permit Program}

The most delicate question under the permit program is how to reconcile EPA's admitted authority over water quality standards with the Secretary of the Army's ultimate power to issue or to deny permits. The regulations acknowledge the dilemma, ${ }^{297}$ then declare that EPA "shall advise" the Corps with respect to the following: "the meaning and content of applicable water quality standards;" "[t] he application of water quality standards to the proposed discharge or deposit, including the likely impact of the proposed discharge or deposit on such water quality standards and related water quality considerations;" and the permit conditions "required to comply with applicable water quality standards" or, where none are applicable, to conform to the purposes of the Act. In the event the District Engineer balks at the recommendations of the Regional Representatives of EPA, review procedures culminating in consultation between the Secretary of the Army and the Administrator of EPA are provided.

Following such consultation, the Secretary shall accept the findings, determinations, and interpretations of the Administrator as to water quality standards, shall direct that the permit be denied if the Administrator found or determined

297 Id. 6566 (to be codified at 33 C.F.R. $\$ 209.131$ (d) (7)) reads in part as follows:

Although the Refuse Act vests in the Secretary of the Army authority to determine whether or not a permit should or should not issue, it is recognized that responsibility for water quality improvement lies primarily with the States - . and, at the Federal level, with the Environmental Protection Agency (EPA). Accordingly, EPA shall advise the Corps with respect to the meaning, content and application of water quality standards applicable to a proposed discharge or deposit and as to the impact which the proposed discharge or deposit may or is likely to have on applicable water quality standards and related water quality considerations, including environmental values reflected in water quality standards. Specifically, the Regional Representative of EPA will, as appropriate, identify and advise the District Engineer with respect to the following:

(i) The meaning and content of applicable water quality standards;

(ii) The application of water quality standards to the proposed discharge or deposit, including the likely impact of the proposed discharge or deposit on such water quality standards and related water quality considerations;

(iii) The permit conditions required to comply with applicable water quality standards;

(iv) The permit conditions required to carry out the purposes of the Federal Water Pollution Control Act where water quality standards are not applicable in whole or in part;

(v) The protection afforded fish and wildlife resources by water quality standards, if any; deposit;

(vi) The interstate water quality effect of the proposed discharge or

(vii) The recommended duration of a permit.

Regional Representatives will also provide District Engineers with a recommendation as to whether or not the permit applied for should or should not issue and the basis for that recommendation. 
that the proposed discharge or deposit would violate applicable water quality standards, and shall give careful consideration to the recommendations of the Administrator before forwarding the case to the District Engineer with instructions as to its disposition. ${ }^{298}$

Thus EPA may dictate water quality conditions appearing in section 13 permits. Here resides the second chance to control water pollution; we may never have a third. The procedure can work as an open-ended invitation to water quality authorities to prescribe conditions before-the-fact that now must be the product of the prolonged suffering called an enforcement proceeding. So, too, treatment objectives feasible before construction can be foreclosed by judgments that cannot be undone for the duration of the life of the plant. Aggressive planning and supervision are required to assure that indeed "the latest available control technology," ${ }^{299}$ rather than general industry practice, is the touchstone. Heavy responsibilities rest upon EPA-and perforce the Corps-to anticipate technological developments that may dictate the control decisions of tomorrow. There is no legal reason why EPA cannot prescribe, and the Corps incorporate, as part of each permit detailed recommendations on water quality, studies, treatment facilities and construction timetables that customarily surface as conference recommendations several years too late. ${ }^{300}$

Though EPA dictation of section 13 permit conditions is desirable, implementing the permit program will be hazardous. The Corps may not readily acquiesce in permit conditions prescribed by EPA. Ex-

29836 Fed. Reg. 6566 (1971) (to be codified at 33 C.F.R. §209.131(d) (10)); see note 6 supra.

299 Section 4 of the Clean Air Amendments of 1970 directs the Administrator of EPA to establish federal standards of performance for new sources. Such standards shall reflect the "degree of emission limitation achievable through the application of the best system of emission reduction which (taking into account the cost of achieving such reduction) the Administrator determines has been adequately demonstrated." 42 U.S.C.A. $\$ 1857 c-6($ a) (1) (1970). The Senate gave this explanation of an earlier (and stronger) draft of the provision:

As used in this section, the term 'available control technology' is intended to mean that the [Administrator] should examine the degree of emission control that has been or can be achieved through the application [of] technology which is available or normally can be made available. This does not mean that the technology must be in actual, routine use somewhere. It does mean that the technology must be available at a cost and at a time which the [Administrator] determines to be reasonable.

Senate Comm. on Public Works, Nationax AIr Quality Standards Act of 1970, S. Rep. No. 1196, 91st Cong., 2d Sess. 16 (1970).

For purposes of this paper, the phrase the "Iatest available control technology" or the "best technology" means a process or a control technology that is commercially available and economically viable. This definition narrows the area of debate somewhat, although, admittedly, it does not foreclose the entire contest. The best technology principle deserves extended discussion, which this Article will not attempt.

300 For the proposition that conference recommendations can be improved substantially, see NADER REPORT, supra note 8 , ch. $\mathrm{X}$, at 13-20. 
perience with the administration of interagency agreements ${ }^{301}$ suggests that by the mid-1970's congressional hearings might document that hundreds of section 13 permits had been issued by the Corps over the express objections of EPA. To remove the temptation, a reorganization proposal transferring section 13 enforcement powers to EPA would be desirable. In an analogous case, the United States Department of Agriculture's power to register chemical pesticides was transferred to EPA ${ }^{302}$ upon a persuasive showing that the Department had been less than faithful in administering its responsibilities.

A stronger reason for a reorganization is the legal risk involved in attempting a full delegation of the Corps' section 13 powers over water quality to EPA. Section 13 says only that permits may be granted "within the limits to be defined and under conditions to be described by the Secretary of the Army." It says nothing about conditions being described by the Administrator of EPA. There are limits on the extent to which the law allows the statutory powers of one official to be exercised de facto by somebody else, whether a subordinate within the same agency or an official in another agency. ${ }^{303}$ This troublesome delegation point already has been raised in litigation challenging the Refuse Act permit program as it affects Lake Michigan. $^{304}$ Whatever the political problems, the legal picture would be clarified if a reorganization transferring section 13 enforcement responsibilities to EPA were accomplished.

It is also tempting to find fault with the decision to articulate standards governing the authorization of discharges in the vaguest of generalities: applicants are told that the administrative judgment will turn upon an evaluation of the discharge on "anchorage and navigation" as well as its compatibility with "applicable water quality standards and related water quality considerations, including environmental values reflected in water quality standards" and "fish and wildlife values not reflected in or adequately protected by applicable water quality standards, if any." 305 This is hardly an advance over the decision of the Corps, announced earlier in 1970, to base permit de-

301 See House Comm. on Government Operations, Deficiencies in AdminisTRATION OF THE FEDERAL INSECTICIDE, FungtCIDE aNd Rodenticide ACT, H.R. ReP. No. 637, 91st Cong., 1st Sess. 5, 14-15 (1969).

302 See note 13 supra.

303 For a recitation of the legal considerations involved, see Hearings on Refuse Act Permit Program Before the Subcomm. on the Enviranment of the Senate Comm. on Commerce, 92d Cong., 1st Sess. 173-216 (1971) (materials supplied by Congressmen Reuss \& Vander Jagt) [hereinafter cited as Refuse Act Hearings].

304 Businessmen for the Public Interest, Inc. v. Resor, Civ. No. 71-894 (N.D. IIl., filed Apr. 12, 1971).

30536 Fed. Reg. 6566 (1971) (to be codified at 33 C.F.R. $\$ \$ 209.131$ (b) (5), (6)). 
cisions on an evaluation of the impact on the "public interest." The utter lack of any firm standard is excusable only in that the agency thus far could do no better than the Congress. Urgent is the need for legislative instruction on the criteria governing the issuance of section 13 permits. Initially, however, the Corps and EPA can specify as ground rules several of the guidelines issued by FWQA to evaluate state water quality standards, notably the non-degradation and besttechnology principles. ${ }^{306}$

Commendable is the announced decision of the administration to define for twenty-two basic industries the state of the art for the treatment of waste. ${ }^{307}$ In practice, however, this means EPA will issue guidelines on "how it construes the treatment requirement in the present standard in most states that industrial discharges receive 'secondary or equivalent treatment." " 308 Thus, the "no discharge" requirement of the Refuse Act is to be construed as requiring only "secondary treatment" already mandated administratively under the Federal Water Pollution Control Act.

It is "openly acknowledged" that secondary treatment is not enough in the nation's most highly polluted areas, and perhaps only temporarily satisfactory elsewhere. ${ }^{309}$ The point has been raised dramatically in a letter to Russell Train, Chairman of the Council on Environmental Quality, by the eight United States Senators from states bordering Lake Michigan, urging that the permit program for that body of water "require the use of the best available and feasible technology, as determined by [EPA], for recycling, reuse, or treatment of pollutants within the shortest practical time." ${ }^{310}$ EPA has responded favorably to the request, taking the position that a 1910 statute ${ }^{311}$ prohibits all discharges, regardless of permits, into defined areas of Lake Michigan. ${ }^{312}$ That is exactly what the statute says. The

306 Gumelines, supra note 146 (nos. 1, 8).

307 See 1971 Hearings, supra note 19, at 29 (testimony of FWQA Comm'r Dominick). Disturbing is EPA's later concession that the "complexities" of these studies "were even greater than we anticipated." EPA News Release 2 (Aug. 5, 1971) (quoting Administrator William D. Ruckleshaus). Abandoning the specific industry guidelines would increase the concern that the federal government is bowing to the states on questions of permit conditions.

308 Remarks by Timothy Atkeson, General Counsel, Council on Environmental Quality to ALI-ABA Seminar on Environmental Law at 5, Jan. 28, 1971; see 1971 Hearings, supra note 19, at 449-56 (describing EPA's current information with respect to industrial pollution control technology).

309 NADER REPORT, supra note 8, ch. XIV, at 19, 20. School.

310 Dated March 31, 1971, copy on file in Biddle Law Library, Univ. of Pa. Law

31133 U.S.C. \$ 421 (1964).

312 See Wall St. J., June 1, 1971, at 7, col. 1 (western ed.); No Refuse Act Permits will be issued in two Iake Michigan counties, Environmental Protection Agency News Release (June 1, 1971). 
consequence for the eight plants affected by the ruling is that they are consigned to the perpetual jeopardy of the pre-permit program days. Like the mercury sources, they are vulnerable to Refuse Act actions aimed at achieving compliance with the "no discharge" mandate. What undoubtedly will occur are individually negotiated treatment programs requiring adoption of the "best" technology looking forward ultimately to complete recycling.

This approach appears equally desirable for other navigable waters and no less legally permissible. As a price for abandoning its life-anddeath leverage under the 1899 Act, EPA should extend the "Lake Michigan" mandate, requiring that permits be conditioned upon commitments to achieve control to the extent of available technology. Where secondary or equivalent treatment will suffice, the regulations could authorize a departure from the "best technology" principle upon a demonstration that a lesser commitment would assure compliance with water quality standards. At a minimum, the statute should be read as imposing the burden on the applicant to justify discharges otherwise strictly forbidden and to prove that the "best technology" is economically indefensible in his case. Those who would introduce a new drug ${ }^{313}$ or pesticide ${ }^{314}$ into commercial channels cannot avoid their obligations to supply test data satisfying the burden of proof of safety. Although new laws would give added confidence, no additional legislative authority is necessary for the Corps to demand a thoroughness of documentation far beyond what is customary in pre-judging applications of American technology. The die is cast on the permit program, and an 1899 act is to produce deliverance or doom.

Where continued substantial discharges appear justified, the permits could require effluent charges, geared to reflect the costs to the environment of continued dumping and designed to provide incentives to strive for ultimate compliance with the "no effluent" standards of the Refuse Act. ${ }^{315}$ The power to forbid all discharges includes a fortiori the power to condition them upon commitments reasonably designed to accomplish the ultimate objective. ${ }^{316}$ The current fee of one hundred dollars for each industrial application, to help defray the cost of ad-

31321 U.S.C. $\$ 355$ (1964).

3147 U.S.C. $\S \S 135-35 \mathrm{c}$ (1964).

315 A similar proposal appears in Rep. Reuss Urges Corps of Engineers to Levy Effluent Charges in Granting Permits for Discharging Wastes Into Waterways, Congressman Henry S. Reuss Press Release (Jan. 8, 1971).

316 The Corps can require payment for the costs of removing shoals caused by the dumping of solids. United States v. Perma Paving Co., 332 F.2d 754 (2d Cir. 1964). The administration takes the position that new legislation is necessary before effluent charges can be imposed upon dischargers under $\S 13$. 
ministering the program, ${ }^{317}$ suggests that the program will be administered with extreme superficiality. A trustworthy scientific estimate of the potential impact of the proposed discharge from a major industrial source would cost several thousand dollars. ${ }^{318}$ One instructive analogue is the investigation required by the AEC of applicants desiring to construct and operate nuclear reactors. ${ }^{319}$ Only an insistence on this kind of in-depth study can lead to internalizing the costs of industrial pollution control.

Standards of disclosure must be similarly stringent. Forms for section 13 permits should be refined with this in mind. Minimal is the directive in the regulations that the form "will also require information which will fully identify the character of the discharge(s) or deposit(s) and describe the monitoring devices and procedures which will be used to gather information and maintain records on discharges and deposits," and that such information "shall include, but need not be limited to, data pertaining to chemical content, water temperature differentials, toxins, sewage, amount and frequency of discharge or deposit and the type and quantity of solids involved, if any." 320 If the discharge includes solids, the applicant is required "to identify the proposed method of instrumentation to determine the effect . . . on the waterway and either . . . assume responsibility for periodic removal . . . or agree to reimburse the United States for the costs [of] dredging." 321

Though a significant departure from the past, these disclosure and monitoring obligations barely scratch the surface. In its prescribed form for section 13 permits the Corps has adopted only part of the disclosure now appearing in the voluntary questionnaire ${ }^{322}$ being distributed in connection with the national inventory of industrial water wastes. A voluntary inventory makes no sense when the vehicle for making it mandatory is at hand. And there can be no doubt about the

31736 Fed. Reg. 6567 (1971) (to be codified at 33 C.F.R. \$209.131(f) (3)).

318 See WASH. Rev. Code ANN. $\$ \S 80.50 .010,80.50 .70$ (Supp. 1970) (authorizing a $\$ 25,000$ filing fee to be applied toward the cost of environmental impact studies).

310 For a description of the process, see Green, Safety Determinations in Nuclear Power Licensing: A Critical View, 43 Notre Dane Law. 633 (1968).

32036 Fed. Reg. 6567 (1971) (to be codified at 36 C.F.R. $\$ 209.131(\mathrm{~g})$ ).

321 Id.

322 Compare U.S. Arny Corps of Engineers, Application for Perarti to Discharge or Work in Navigable Waters and TherR Tributaries, ENG Form S 4345 , 4345-1 (May, 1971), on file in Biddle Law Library, Univ. of Pa. Law School, with WASTES INVENTORY HEARINGS, sitpra note 10, at 79-81 (FWQA Form 120 (Rev. 4-70)) (App. 3). That data gathering nonetheless is likely to be the most significant contribution of the program is indicated by the detailed instructions for filling out the

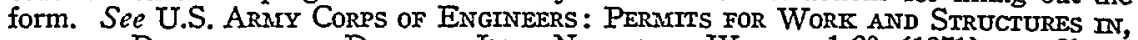
AND FOR Discharges oR Deposirs INTo NAVIGABLE Waters 1-20 (1971), on file in Biddle Law Library, Univ. of Pa. Law School. 
value and relevance of the information there sought, including data on waste treatment facilities, costs, manpower requirements, and composition of the effluent, to the objectives of the section 13 permit program. Moreover, it is essential that the present opportunities be exploited by prescribing in all section 13 permits such novel but minimal precautions as : continuous monitoring of the effluent, unannounced onsite inspections, regular surveillance, disclosures about the processes and, in some cases, the economics of a particular plant, a specification of circumstances of revocability, and extensive data on the impact of the discharge on the water environment. From all appearances, these demands will be made superficially if at all.

Most disturbing is EPA's reluctance to assume a general authority to review-and to modify-conditions affecting discharges into intrastate navigable waters over which there is presently no authority under the Federal Water Pollution Control Act to establish water quality standards. ${ }^{323}$ The position amounts to relinquishing the regulatory opportunities of the Refuse Act for legislation with a lesser reach. The danger is that an uncritical acceptance of the state certification under section 21 (b) (1) of the Federal Water Pollution Control Act ${ }^{324}$ as a full measure ${ }^{325}$ of the effuent standards applied by the Corps to dis-

323 The nuances of the administration's position on this point are spelled out in NADER REPoRT, supra note 8, ch. XV. See Friends of the Earth and the Natural Resources Defense Council, Comments on Proposed Documents Relating to the Refuse Act Permit Program (Feb. 26, 1971).

32433 U.S.C.A. $\$ 1171$ (b) (1). In the face of harsh criticism, the Atomic Energy Commission, like the Corps, assumed that the states essentially retained a veto power over all permit conditions by reason of their authority to certify under the Water Quality Act of 1970. The Commission, upon this interpretation, eschews responsibility for making judgments about environmental impact under either the 1970 Water Quality Improvement Act, or the National Environmental Policy Act of 1969, 42 UU.S.C. $\$ \S 4331-35,4341-47$ (Supp. V, 1970). See Letter from Commissioner James T. Ramey to the Editor, N.Y. Times, Oct. 10, 1970, at 24, col. 7. Calvert Cliffs' Coordinating Comm., Inc. v. AEC, 40 U.S.L.W. 2067 (D.C. Cír. Aug. 3, 1971), will force a reevaluation by the Commission of its environmental responsibilities.

Over the long run, it may prove more sensible to allow agencies with specialized environmental responsibilities to dictate the conditions appearing in permits from the "building" agencies, like the Corps or the AEC. This suggests that enforcement of $\$ 13$ ultimately belongs in the hands of EPA.

325 EPA offers this explanation of the differences of the permit program on interstate and intrastate waters:

EPA's role will be broader with respect to standards for interstate waters, which have been developed by States subject to Federal approval, than with respect to standards for intrastate waters, which under present law are entirely the responsibility of the States. In the case of standards for interstate waters, EPA will be providing the Corps with both factual determinations and interpretations of their meaning, content and application. In the case of standards for intrastate waters, EPA will provide factual determinations but will defer to the States with respect to interpretations of their meaning and application in particular circumstances.

1971 Hearings, supra note 19, at 426. This "deference" appears to mean that EPA will accept uncritically state conditions imposed on sources discharging into intrastate waters. It is extremely questionable whether what a state says about its water quality standards should control the Corps' judgment about its effluent standards. 
charges into navigable waters will raise the spectre of the well-publicized licenses to pollute. ${ }^{326}$ The states, after all, have been known to be less than demanding of certain major industries. That the permit program has been initiated upon the assumption that the federal government presently has no legislative authority to dictate intrastate standards (and perforce effluent requirements for sources discharging into intrastate waters) lends credence to the charge that what we are witnessing is the de facto repudiation of the Refuse Act.

A word about public hearings. Under the regulations, a public hearing will be held in connection with section 13 permits "whenever, in the opinion of the District Engineer, such a hearing is advisable." 327 The regulations enumerate three considerations to be weighed in making this determination:

the degree of interest by the public in the permit application, requests by responsible Federal, State, or local authorities, including Members of the Congress, that a hearing be held, and the likelihood that information will be presented at the hearing that will be of assistance in determining whether the permit applied for will be issued. ${ }^{328}$

Typically, in this formulation the Corps preserves maximum administrative autonomy. Tying a hearing to professional or political interest by governmental officials appears to make sense. The difficulty arises in determining the substantiality of the public interest or the degree to which the information promised is "of assistance in determining whether the permit applied for will be issued." Citizen groups across the country are in the process of finding out whether twenty, thirty, or more inquiries, or a demonstration, or a press conference suffices to show a "substantial" public interest. More to the point is the nature of the hearing. The Corps has resisted contested hearings and section 13 procedures will follow this pattern. ${ }^{329}$ If experience indicates that the states relinquish the opportunities to explore fully the problems in the certification proceedings, the case for a legislative look at the Corps' hearing procedures will be that much stronger.

\section{The Second Chance for Water Quality}

For industrial polluters, it may appear that the betrayal has been complete. A Covington \& Burling lawyer, who once argued that Secre-

320 Refuse Act Hearings, supra note 303, at 176.

32736 Fed. Reg. 6569 (1971) (to be codified at 33 C.F.R. $\$ 209.131(\mathrm{k})$ ).

$328 \mathrm{Id}$.

329 See note 291 supra. 
tary Udall's non-degradation guidelines were inconsistent with the Federal Water Quality Act of 1965, has pointed out that an earlier version of the certification procedures now appearing in the 1970 amendments may mean that "many of the safeguards" in existing law "may well provide only illusory protection against arbitrary or unreasonable action by the Secretary of Interior, the licensing agency, or the affected States." ${ }^{330}$ It may be conceded that the new procedures represent a repudiation of the 1965 program as thoroughly as that year's enactment ignored the underlying philosophy of the 1899 Refuse Act. Although no frontal legal assault has been made on the "talk-itout" methodology of the conference format, still, the potential for such an attack has been effected by the enveloping movement of the Fish and Wildlife Coordination Act, NEPA, the 1970 amendments and the revived Refuse Act.

Consider one possible scenario that might emerge in the next few years: virtually all major contributors of industrial waste to navigable waters stand condemned under a criminal statute with a potentially crushing liability up to $\$ 2,500$ a day. An aggressive, concerned Attorney General is anxious to exercise his authority and use his considerable leverage effectively to assure water quality. State certification lies ahead. It is likely, given the recent upsurge of public opinion, that most states will exercise the option to hold public hearings, which should be well attended by the usual throng of irate citizens. Lawyers will argue that the hearings should be conducted as "contested cases," with full rights of cross-examination and discovery. In many cases this thorough, almost-unheard-of, before-the-fact analysis will result in a new understanding of the control objectives that are essential in the public interest. State officials will seize the opportunity to repair deficiencies in existing data, to impose further industry-financed study obligations on the applicant, and to bring treatment timetables and objectives into line with current concerns about the toxic metals, nitrogen, phosphorus, and carbon, which add a new dimension to an already serious problem. All this activity is justifiable to support a judgment by the state that "reasonable assurance" can be given to the licensing federal agency that water quality standards will be satisfied.

Having cleared the hurdle of the state certification proceeding, the applicant still must satisfy the Corps' requirements. Under revised rules, public hearings are probable if not mandatory. The Corps will demand detailed engineering plans and disclosure about the effluent, the nature of the manufacturing process, and the economics of the enterprise. The Fish and Wildlife Service will make known its concerns on the basis 
of the administrative understanding that the Corps will accede to all requested study, disclosure, or monitoring conditions, even to the extent of vetoing a proposed site thought to be incompatible with a protection of valuable marine resources. EPA can exercise a preventive authority it has never before enjoyed. There will be no more prerequisites to action that pollution in one state must cause health hazards in another. ${ }^{331}$ No more obligations to prove that the fish kill near the chemical plant actually was caused by the suspected culprit. No more useless two million dollar studies proving that sulfite waste liquor harms oysters which end when statehouse politics render useless those scientific efforts. $^{332}$ Instead, EPA, acting with the approval of the Corps, can specify necessary studies, treatment, and monitoring precautions as a condition to the permit. It can insist upon the non-degradation and best-technology principles now virtually ignored. It can, in short, reclaim much of the authority it has been denied under the Federal Water Pollution Control Act.

Another scenario, however, may emerge under a new reading of the Refuse Act. The criminal violations, after all, are mere technicalities that will be excused by an understanding Attorney General. The public, unaware of its potential right to a hearing in the state certification procedures, will create scarcely a ripple as state officials routinely ignore what at best is an inconvenience. Unprepared, uninspired, and disinterested, these same officials may perceive the certification as but another piece of paper to sign. "After all, we have commitments and arrangements with these industries, however unsatisfactory they may be, which can't be repudiated just because the federal government discovers an old law." Worse, existing state permits may be treated routinely as state certifications or the requirement may be waived automatically with no thought given to nascent regulatory opportunities. EPA of course has a certain way of doing things-negotiations, studies, conferences, progress meetings to review "slippage," and an enforcement action perhaps every ten or twelve years. "It would be inconsistent with our historic role to attempt to dictate to any industry or state what technology is desirable or what monitoring and impact studies are needed," according to this classic understanding.

331 See 33 U.S.C.A. $\$ 1160$ (d) (1) (1970).

332 The reference is to the massive studies by federal officials of the impact of sulfite waste liquor from pulp mills on the oyster and sole fisheries of Puget Sound. Federal Water Pollution Control Administration, Pollutional Effects of Pulp and Paper Mitr. Wastes tN Puget Sound (1967); see Wilson, Puget Sound Pollution: $A$ Case History, Seattle Times, Feb. 16, 1970, at 1, cols. 7-8 (reprinted from the Washington Post). 
The Corps, it must be admitted, now considers ecology as well as navigation. Nevertheless, "the District and Division Engineers recommend that the permit be granted since the issues raised concerning riparian rights, conservation, recreation and pollution have been resolved insofar as the responsible Federal [and state] agencies are concerned, [and] there is no objection to the proposed work from the standpoint of navigation ...." 333

If there are unanswered objections from other agencies, they may be ignored because the Corps has the final word and all agree that the principal purpose of the Refuse Act is to prevent obstructions to navigation. Besides, it is unrealistic to expect instant changes in the traditions, outlook, and personnel of an agency whose mission is foreign to concerns about improved water quality. Funding proposals to strengthen the Corps' responsiveness are quietly shelved. Within several months, thousands of permits are issued. There are no more crimes and no more embarrassments. There may still be water pollution but that is being eliminated in accordance with the elaborate procedures of the Federal Water Pollution Control Act "with all deliberate speed."

333 Hunting Creek Report, supra note 106, at 41. 